\title{
Local Economic Spillover Effects of Stock Market Listings
}

\author{
Alexander W. Butler, Larry Fauver, and Ioannis Spyridopoulos®*
}

\begin{abstract}
We show that initial public offerings (IPOs) have nontrivial positive spillover effects on local labor markets, business environments, consumer spending, real estate, and migration. We mitigate endogeneity concerns about unobserved heterogeneity with restrictive geographic fixed effects coupled with a matching procedure. We show that it is the listing decision, which encompasses both a wealth and liquidity shock, that induces economic spillovers. Conditional on an IPO occurring, we estimate that an additional \$10 million in IPO proceeds is associated with an extra 41 jobs and 0.7 new establishments locally.
\end{abstract}

\section{Introduction}

Anecdotal evidence suggests that the change in the listing status of a firm and the concomitant liquidity it provides its shareholders can significantly affect local economies. An example is Facebook. The Facebook initial public offering (IPO) was enormous, raising over $\$ 16$ billion and making liquid the paper wealth that many Facebook employees had in the form of previously illiquid stock. As the author of one article on the Facebook IPO states, "When Facebook CEO Mark Zuckerberg rang the NASDAQ opening bell on Friday [May 18, 2012] to mark Facebook's public debut, he also rang in a crop of new millionaires and billionaires" (http://money.cnn.com/2012/05/21/technology/facebook-ipo-millionaires/ index.htm).

\footnotetext{
*Butler, alex.butler@rice.edu, Rice University Jones Graduate School of Business; Fauver, lafauver@utk.edu, University of Tennessee Haslam College of Business; and Spyridopoulos, ispyrido@american.edu, American University Kogod School of Business. Without implicating them, we thank Dan Bradley, Jamie Brown, Lee Ann Butler, Deborah Fauver, Yianni Floros, Zoran Ivkovich, Paul Malatesta (the editor), Andy Naranjo, Jay Ritter (the referee), seminar participants at the NYSE, Iowa State University, Rice University, Baylor University, Vanderbilt University, University of Texas at El Paso, University of Tennessee, Cal Poly, University of Florida, Texas Tech University, University of Alabama, the 2016 PNC University of Kentucky Finance Conference, 2016 Financial Management Association doctoral student consortium, the 2018 Midwest Finance Association conference, the 2018 Eastern Finance Association conference, the 2018 U.S. Securities and Exchange Commission conference, and the 2018 Southern Finance Association conference for helpful comments. We thank Michael McDonald for contributions on an earlier draft. Any errors are ours.
} 
Without providing exact numbers, the authors of that article and others from around the same time suggest that thousands of Facebook employees became millionaires in the transaction. The author of another article from the time speculates that the Facebook IPO could create more than $\$ 1$ billion in property value in the San Francisco Bay area near the company's headquarters in Palo Alto, CA, due to the number of millionaires competing to buy homes (http://www.huffingtonpost.com/david-j-cross/san-francisco-real-estate_b_1527172.html). This phenomenon is not unique to Facebook; more than two decades earlier, Dell went public, creating liquidity for numerous employee-shareholders in the Austin, TX area near Dell's headquarters. These employees, sometimes referred to as "Dellionaires," got rich off their shareholdings and bought and built homes in the area, thereby popularizing the term "McMansion," which describes their ubiquitous domiciles. ${ }^{1}$

We study whether IPOs are associated with positive economic spillover effects near the firms' headquarters. We find that IPOs have a significant and broad effect on local real estate outcomes (home prices and mortgage originations), labor market outcomes (employment growth), and other measures of economic growth (establishments' growth and individuals' credit card spending). But why? An IPO does not create a new firm, but it does create significant liquidity for the firm and the employees, and other shareholders who own shares of the newly listed firm. The IPO also affects investor wealth if the firm's stock price increases after listing, and it affects firm "wealth" by raising new capital. We provide evidence that both liquidity and wealth effects on investors are important channels for these local impacts from the IPO.

Identification problems arising from reverse causality and omitted variable bias are possible. To address these identification challenges, we compare outcomes for the specific locations (their ZIP codes) within a county where IPO firms have their headquarters to other areas of the same county in the same year. Our main identifying assumption is that the choice of the location of the headquarters' ZIP code within a county when the firm is founded ( 8 years before the firm files for an IPO for the median in our sample) is independent of the long-run economic development of that specific ZIP code relative to other similar ZIP codes nearby. We construct plausible counterfactuals using matched no-IPO ZIP codes in the same county and year with similar ZIP code level characteristics and past IPO activity.

This approach to estimating an IPO's effect on the local economy forces identification from differences in geographic proximity of ZIP codes to the headquarters of a newly listed firm. The design mitigates concerns over omitted variable bias because an offending omitted variable would have to be correlated with our outcome variables and our explanatory IPO activity variable, and would have to vary by proximity to the IPO firm headquarters within the same county and year after conditioning on our control variables. The approach is nuanced, and we subsequently explain it in more detail.

We use this empirical design to study how IPOs affect the local economy around the IPO headquarters. We start with an examination of real estate outcomes and find home price growth increases by more than one-third, from $2.8 \%$

\footnotetext{
${ }^{1}$ Austin, TX has residential design ordinances colloquially known as "McMansion regulations." See http://www.austintexas.gov/department/residential-design-compatability-standards.
} 
to $3.7 \%$, in ZIP codes located within 2 miles from the IPO headquarters, but only for expensive houses. This home price growth declines with a ZIP code's distance from the IPO headquarters. Consistent with the possibility that home price growth is driven by new purchases, we find that the average and total mortgage amount growth is higher in ZIP codes nearer the IPO headquarters.

Do the real estate effects reflect that IPO shareholders now have more liquid stock in the firm due to its listing? Or do the results stem from a change in the wealth of those investors? We find evidence of both. Home price growth accelerates after the expiration of the lockup period, when shareholders can sell their stock. Moreover, this home price growth is higher for listings in which the firm's stock market price increases in the post-IPO period. A placebo test further supports the intuition: Buyout-backed IPOs are owned mainly by private equity firms and their limited partners, who are primarily institutional investors, rather than IPO-firm employees. These institutional investors are less likely to live close to the company headquarters and less likely to affect local housing demand. Using buyout-backed IPOs as placebo events, we confirm that the lack of local investors mutes the IPO-spillover effects.

Is the economic spillover effect driven by its employees and investors or by the firm itself (i.e., raising external capital)? To assess whether the spillovers are due to a capital-raising effect, we include in our tests a variable that reflects seasoned equity offering (SEO) activity in the area. When we do so, the SEO activity variable is statistically insignificant. We interpret this finding as being consistent with changes in firms' listing status, rather than simply a capital raising event, explaining the economic spillover effects.

We examine possible channels of the IPO spillover effects. IPOs could affect local labor markets and business development through either direct or indirect channels. For instance, Kenney, Patton, and Ritter (2012) show that firm employment grows at an annual rate of $6 \%$ to $7 \%$ after the firm goes public (a direct effect). Consistent with a direct effect, we find that annual employment growth in IPO headquarters ZIP codes increases from an average of $1.4 \%$ to an average of $2 \%$.

An indirect channel through which IPOs may affect the local economy is through investors' higher home prices and spending (Mian, Rao, and Sufi (2013), Mian and Sufi (2014)). Recent studies use changes in home prices to proxy for local wealth shocks and find an increase in employment growth (Schmalz, Sraer, and Thesmar (2017)), and establishment growth (Adelino, Schoar, and Severino (2015)). We find evidence consistent with a local demand-driven IPO effect on business development. IPOs have a large effect on the growth of retail establishments and construction near the IPO headquarters ZIP code but do not affect establishments that depend on national, rather than local, demand (i.e., businesses in the tradable sector). We also find that local consumers' credit card spending increases near the IPO headquarters, providing further support for the hypothesis that IPO effects on the local economy are demand-driven. Finally, we document changes in post-IPO migration patterns: Low-income people are $0.7 \%-1.5 \%$ more likely to move away to ZIP codes with lower average income or lower housing costs increases.

In addition to these extensive margin tests, we quantify the intensive margin. Conditional on a change in listing status, IPOs with larger proceeds may have 
larger effects on local economic outcomes. Holding other factors equal, we estimate that the incremental effect of an extra $\$ 10$ million in IPO proceeds is, on average, 41 new employees in the county, of which approximately $69 \%$ are in the IPO firm's headquarters ZIP code, and $31 \%$ are not. Our intensive margin calculations also show an increase in the number of business establishments in the county by 0.7 per additional $\$ 10$ million proceeds.

Our paper adds to the finance-growth nexus literature (Jayaratne and Strahan (1996), Levine (2005)), particularly on how equity market access affects local economies. We show that firm-level changes in listing status affect the surrounding geographic area's real estate, labor, and business development, and thus we provide some micro-foundation evidence for the country-level results in the literature and some macro-implications consistent with the company-level results in the literature. This study fits between the literature that examines how a firm's equity issues (Brown, Fazzari, and Petersen (2009), Brown and Floros (2012)) and listing status (Acharya and $\mathrm{Xu}$ (2016)) affect company activity and growth, and the literature on how country-level equity market features affect country-level growth (Bekaert, Harvey, and Lundblad (2005), Beck and Levine (2004), and Brown, Martinsson, and Petersen (2013)). The positive local economic spillover effects of IPOs we document here are consistent with studies that link household wealth with employment (Mian et al. (2013), Mian and Sufi (2014)), employee wealth with increases in entrepreneurship (Cagetti and De Nardi (2006), Babina, Ouimet, and Zarutskie (2017)), and entrepreneurship with job creation (Haltiwanger, Jarmin, and Miranda (2013)).

\section{Methods and Data}

\section{A. Empirical Design and Identifying Assumptions}

Our main tests use a restrictive fixed effects approach to mitigate concerns of unobservable factors driving our results. Specifically, we use county-year fixed effects and examine the variation in economic outcomes across ZIP codes within the county and the year of a company going public. Like all empirical designs, this approach has strengths and weaknesses. It does not address reverse causality (we have several tests, in the Supplementary Material, that address this issue). But our empirical design does control for a wide variety of time- and geography-varying factors. For an omitted variable to bias our coefficient estimates, it would have to vary only across ZIP codes within county and within year, and to be correlated with IPO activity but not our control variables. Our main identifying assumption is the following: In the absence of a significant local shock, such as an IPO, the change in the economic development of nearby ZIP codes in a given year should be similar on average.

Here we note some data management choices, and we relegate a detailed discussion of this empirical design and its interpretation to the Supplementary Material. We exclude ZIP codes that have never had an IPO from 1990 to 2015, making our treated and control samples more homogeneous. Over time, IPOs are dispersed across several different ZIP codes in a given county; therefore, a ZIP code with an IPO in one year (treated) may instead serve as a control ZIP code in another year. 
To induce homogeneity of our treated and control ZIP-year observations, we use a matching procedure. Within a given county and year, we match ZIP codes that had an IPO with ZIP codes that have no IPOs based on the lagged number of establishments and employment. To balance inclusiveness of observations with closeness of match along these dimensions, we use coarsened exact matching (see Blackwell, Iacus, and Porro (2009)). The procedure is similar to characteristic matching, but rather than trying to match well on multiple continuous dimensions, such as the characteristic matching in Barber and Lyon (1997), we match exactly on discretized bins of these variables. The result is a categorical match on every dimension for every observation that we use. We cut (or coarsen) these covariates into five groups based on the yearly distribution of their values. This process creates a number of dimensional strata, or bins. Finally, we put all our observations into these bins and make sure that each bin has at least one observation from the treated and control groups. We drop all observations that do not satisfy the above criteria. We repeat this matching process for each outcome variable we study. Once we match, the standardized differences suggest that our matched sample contains only ZIP codes with well-balanced characteristics, with all the standardized differences close to 0 .

\section{B. Structure and Interpretation of Tests}

Our empirical model allows us to estimate IPO spillover effects within a county-year based on each ZIP code's distance from the IPO. Most of our tests are structured as follows:

$$
\begin{aligned}
& \left(\bar{Y} \_ \text {GROWTH }\right)_{i, j, t+1}=\beta_{1}(\text { IPO_HEADQUARTERS_ZIP_CODE })_{i, t} \\
& \quad+\beta_{2}(\text { WITHIN_2_MILES_OF_IPO_HEADQUARTERS })_{i, t} \\
& \quad+\beta_{3}(\text { BETWEEN_2-5_MILES_FROM_IPO_HEADQUARTERS })_{i, t} \\
& \quad+\beta_{4}(\text { BETWEEN_5-10_MILES_FROM_IPO_HEADQUARTERS })_{i, t} \\
& \quad+\gamma(\text { ZIP_SEO }>0)_{i, t}+\alpha_{j, t}+\mathbf{X}_{i, t}+\epsilon_{i, j, t+1} .
\end{aligned}
$$

In regression (1), the dependent variable $\left(\bar{Y}_{-} \text {GROWTH }\right)_{i, j, t+1}$ is the 2-year average annual growth of economic variables that reflect activity in real estate, economic development and growth, and consumer behavior (home price index, home value for top-, middle-, and bottom-tier houses, mortgage amounts, employment, business establishments, and credit card spending). We use the 2-year average growth rate because the effect of the IPO in the local economy may take longer than 1 year to show in the data, and many of our variables are measured at an annual frequency. The pair $i, t$ indicates ZIP code-year, which is the main unit of observation in our sample. $\mathbf{X}_{i, t}$ is a vector of lagged ZIP code control variables (LN(POPULATION), LN(POPULATION_DENSITY), LN(ESTABLISHMENTS), LN(EMPLOYMENT), and LN(WAGE_INCOME), and the lagged dependent variable). The regressions include county-year fixed effects $\left(\alpha_{j, t}\right){ }^{2}$

\footnotetext{
${ }^{2}$ We use restrictive county-year fixed effects for our baseline specifications because they force identification from IPO activity across ZIP codes in the same county and year. When we apply a fixed effect for each ZIP code and a fixed effect for each year we find economically larger IPO spillover effects. These results are in our Supplementary Material, Section A.II.
} 
The coefficient $\beta_{1}$ reflects the difference in the annual growth rate of $Y$ between the IPO headquarters ZIP code and all ZIP codes with no IPO activity in the same county and year. The coefficient $\beta_{2}$ captures the difference in the growth rate of $Y$ between ZIP codes located within 2 miles from the IPO and ZIP codes outside this radius. ${ }^{3}$ Similarly, estimators $\beta_{3}$ and $\beta_{4}$ capture the difference in the growth rate of $Y$ between ZIP codes located 2-5 miles and 5-10 miles from ZIP codes in the same county and year located outside the respective radius. Importantly, every ZIP code in our sample serves both as a treated observation at least once and as a control observation, at varying distances, potentially in many different years. This cross-ZIP code heterogeneity in IPOs over time and the ZIP code's distance from an IPO allows us to identify a plausible counterfactual for what the change in outcome $Y$ would have been without the IPO. ${ }^{4}$

\section{Data}

We gather IPO data on U.S. firms from the Securities Data Corporation (SDC) from 1998 to 2015 and use the address of each firm's headquarters to determine its associated ZIP code. Some firms may have operations in geographic areas distant from their headquarters, especially large firms. This geographic dispersion should bias our estimates toward 0 because we treat them as control ZIP code-years, when in fact they could be considered treated. We exclude firms with missing information on ZIP code or filing amount and, following Ritter and Welch (2002), and Gao, Ritter, and Zhu (2013), also remove from the sample foreign issuers, exchange-traded funds, real estate investment trusts, nonstocks, and financials. ${ }^{5}$ We retain spinoffs and IPOs whose offer price is less than $\$ 5$, but when we exclude them our regression estimates are generally $10 \%-30 \%$ larger in magnitude. We also include data on ZIP code-year seasoned equity offerings (SEOs) and use these as placebo events because, unlike IPOs, they do not affect the firm's listing status, although they do involve raising capital and providing liquidity.

Even though SDC provides details about the timing, location, and characteristics of IPOs in the U.S. since the 1970s, our need for economic data at the ZIP code level limits the time series of the panel. Our sample is from 1998 to 2015, excluding years 1999, 2000, and 2003 because of the lack of income data at the ZIP code level. For tests that examine credit card spending and migration patterns, our sample period is from 2005 to 2015 . We also have tests, relegated to the Supplementary Material, that expand the external validity of our main results by using larger geographic units and a longer sample period.

We construct a ZIP code-year panel data set of annual income, employment, business, real estate, and credit card spending data from various data sets. Data on population and population density (population divided by ZIP code land area) are from the U.S. Census files. We calculate ZIP code per capita income from the

${ }^{3}$ ZIP codes have irregular boundaries (or shapes), thus in order to calculate the distance between two ZIP codes we compute the mile-distance of a straight line between their centroids, or the center of the mass of their area.

${ }^{4}$ We provide a more extensive illustration of our identification approach in the Supplementary Material (see Section A.I, Figures A.1-A.3).

${ }^{5}$ Specifically, we exclude the following security types: Unit offers, trust units, stock units, limited partnerships, master limited partnerships, and security types that appear in SDC as "Beneficial Ints," "Shs Benficl Int," and "Ltd Liab Int." We also exclude closed-end funds. 
Internal Revenue Service's Statistics of Income data. U.S. Census ZIP Code Business Patterns data add annual information on employment and the total number of establishments. The Census business pattern data sets break down the annual number of establishments in the ZIP code by North American Industry Classification System (NAICS) code and by establishment size (based on the number of employees). Following the NAICS codes from Mian and Sufi (2014), we calculate the total number of establishments in three sectors: The tradable sector, the nontradable sector, and construction. The tradable sector includes establishments whose growth depends on national or global demand for the firm (i.e., they have imports or exports). Local IPO investors are less likely to affect this sector. On the other hand, the nontradable sector includes business in retail and restaurants, and construction includes businesses in real estate development.

The Federal Housing Finance Agency (FHFA) provides annual ZIP code home price index data. The FHFA does not break down home prices by size category, thus we complement our home price data using Zillow. Based on how expensive the house is, Zillow provides home values for top-, middle-, and bottom-tier homes. Our real estate variables also include annual data on mortgage origination from the Home Mortgage Disclosure Act (HMDA) data. HMDA provides individual-level data on mortgage originations that we aggregate at the ZIP codelevel in order to calculate the total number of mortgage applications, the total amount originated, and the average mortgage amount in the ZIP code.

Finally, we use a large sample of individual-level consumer finance data from Experian. ${ }^{6}$ The credit bureau data set includes annual data on credit card consumption and the associated ZIP code of the person's location. Using this data set, we construct the average annual credit card spending in the ZIP code. For our sample of people in the Experian data set, we locate the ZIP code of each person's residence and trace migration patterns across different ZIP codes around the timing of local IPOs.

Although the results are insensitive to doing so, we winsorize all variables at the 1st and 99th percentiles of their empirical distributions. Winsorizing mitigates the effects of outliers, such as those from local economies that may experience large changes in our outcome variables because of exogenous events (e.g., natural disasters).

\section{Summary Statistics}

Table 1 reports summary statistics for the main variables. Our final sample consists of 1,365 ZIP codes that have at least one IPO. The vast majority of ZIP codes have no more than one IPO in a given year, which suggests that there is significant heterogeneity within a county related to the location of IPOs. The average proceeds (not adjusted for inflation) from all IPOs in a given ZIP-year are approximately \$130 million (\$266 million for large IPOs), conditional on there being at least one IPO.

Panel B of Table 1 shows the average ZIP code characteristics. The average per capita ZIP code wage income in the sample is approximately $\$ 60,000$, which

\footnotetext{
${ }^{6}$ Our sample from Experian for 2005-2015 is a representative random sample of $1 \%$ of the U.S. population. It contains information on all people with credit reports whose social security number ends in a particular 2-digit number.
} 
TABLE 1

Summary Statistics

Table 1 reports the summary statistics for variables related to ZIP code and IPO. In the list of IPO variables in Panel A, we calculate the total number of IPOs (IPO_\#) and the sum of all the proceeds from IPOs in the ZIP code (IPO_PROCEEDS) in a given year, conditional on having at least one IPO. We also calculate the total number of large IPOs (LARGE_IPO_\#) and the sum of all the proceeds from large IPOs (LARGE_IPO_PROCEEDS) in the ZIP code (large IPO is an IPO whose proceeds are in the top quartile of proceeds of all IPOs in a given year). Panel A includes the number of seasoned equity offerings (SEO_\#) and the sum of the proceeds of the SEO issues (SEO_PROCEEDS) in a given year. Our sample period is from 1998 to 2015, excluding the years 1999, 2000, and 2003. Panel B shows the set of economic variables we use as controls or dependent variables in our sample. WAGE_INCOME is the average per capita wage income reported in individual tax returns from the Internal Revenue Service. EMPLOYMENT is the number of employed people in the ZIP code, and ESTABLISHMENTS is the total number of businesses in the ZIP code. The HOME_PRICE_INDEX is from the Federal Housing Finance Agency and is based on $2000(=100)$ home prices for each ZIP code. MORTGAGE_AMOUNT is from HMDA and represents the total amount of mortgages originated in the ZIP code divided by the total number of approved applications. CR_CARD_SPENDING represents the average dollar amount that people living in the ZIP code spent using their credit cards. In Panel C, columns 1 and 2 present the average characteristics (in the prior year) for ZIP codes with no IPO activity $(I P O=0)$ and with at least one IPO (IPO HQ ZIP CODE), respectively. Column 3 shows univariate differences for the economic variables, and the last column shows univariate differences in terms of their standard deviation (normalized).

\begin{tabular}{|c|c|c|c|c|c|c|}
\hline & $N$ & Mean & Std. Dev. & $\underline{\mathrm{P} 10}$ & P50 & $\mathrm{P} 90$ \\
\hline \multicolumn{7}{|c|}{ Panel A. ZIP Code IPO Characteristics (for ZIP Codes with IPO_HQ_ZIP_CODE) } \\
\hline IPO_\# & 2,426 & 1.24 & 0.72 & 1.00 & 1.00 & 2.00 \\
\hline IPO_PROCEEDS & 2,426 & 130.63 & 283.64 & 20.00 & 70.59 & 279.30 \\
\hline LARGE_IPO_\# & 826 & 1.36 & 0.90 & 1.00 & 1.00 & 2.00 \\
\hline LARGE_IPO_PROCEEDS & 826 & 266.57 & 450.61 & 68.00 & 170.19 & 510.00 \\
\hline SEO_\# & 2,759 & 1.59 & 1.22 & 1.00 & 1.00 & 3.00 \\
\hline SEO_PROCEEDS & 2,759 & 192.48 & 236.37 & 17.42 & 90.75 & 587.76 \\
\hline \multicolumn{7}{|c|}{ Panel B. ZIP Code Economic Characteristics } \\
\hline POPULATION (000s) & 10,661 & 30.06 & 14.60 & 12.93 & 28.43 & 49.03 \\
\hline WAGE_INCOME (O0Os) & 10,661 & 60.24 & 29.40 & 31.13 & 53.81 & 96.65 \\
\hline EMPLOYMENT (000s) & 10,661 & 24.61 & 16.64 & 6.99 & 20.79 & 47.72 \\
\hline ESTABLISHMENTS (000s) & 10,661 & 1.20 & 0.64 & 0.44 & 1.12 & 2.10 \\
\hline HOME_PRICE_INDEX & 10,651 & 138.99 & 34.46 & 99.21 & 135.10 & 184.54 \\
\hline MORTGAGE_AMOUNT (000s) & 9,720 & 280.03 & 145.05 & 128.97 & 253.74 & 455.28 \\
\hline CR_CARD_SPENDING (000s) & 6,642 & 18.22 & 12.53 & 7.26 & 14.45 & 33.82 \\
\hline$\% \Delta(\mathrm{HPI})$ & 9,850 & 3.19 & 7.19 & -5.47 & 3.07 & 12.69 \\
\hline$\% \Delta$ (EMPLOYMENT) & 9,851 & 1.39 & 6.79 & -5.72 & 1.16 & 8.04 \\
\hline$\% \Delta$ (ESTABLISHMENTS) & 9,886 & 0.97 & 3.02 & -1.96 & 0.71 & 3.92 \\
\hline$\% \Delta($ INCOME $)$ & 8,395 & 3.17 & 5.13 & -2.48 & 3.04 & 8.92 \\
\hline$\% \Delta$ (WAGE_INCOME) & 8,395 & 2.78 & 3.19 & -0.50 & 2.60 & 6.52 \\
\hline$\% \Delta$ (MORTGAGE_AMOUNT) & 7,927 & 3.91 & 8.91 & -5.57 & 3.38 & 13.47 \\
\hline$\% \Delta$ (CR_CARD_SPENDING) & 5,456 & 13.27 & 21.94 & -8.92 & 8.10 & 44.20 \\
\hline
\end{tabular}

Panel C. IPO versus Non-IPO ZIP-Years: Univariate Differences

\begin{tabular}{|c|c|c|c|c|}
\hline & $\begin{array}{c}\text { Treated: } \\
\text { At Least One IPO } \\
\text { in the ZIP-Year } \\
1\end{array}$ & $\begin{array}{l}\text { Matched Controls: } \\
\text { No IPOs in } \\
\text { ZIP-Year } \\
2\end{array}$ & $\begin{array}{c}\text { Difference } \\
2-1\end{array}$ & $\begin{array}{c}\text { Difference } \\
\text { (normalized) } \\
2-1\end{array}$ \\
\hline EMPLOYMENT & 24,749 & 24,596 & -153 & -0.011 \\
\hline ESTABLISHMENTS & 1,201 & 1,205 & 4 & 0.001 \\
\hline WAGE_INCOME & 60,710 & 60,180 & -530 & -0.029 \\
\hline HOME_PRICE_INDEX & 136.81 & 139.50 & 2.69 & 0.062 \\
\hline CR_CARD_SPENDING & 19,123 & 18,177 & -946 & -0.079 \\
\hline MORTGAGE_AMOUNT & 276,930 & 281,220 & 4,290 & 0.022 \\
\hline
\end{tabular}

is larger than the overall U.S. average. Counties with more business establishments have higher income, which explains why our ZIP code income, employment, and business establishment averages are higher after we exclude ZIP codes that have never had an IPO during the sample period. The average ZIP code in our sample has approximately 24,000 people employed and 1,200 business establishments. The average home price index is 138 (with the year 2000 as a basis of 100 ), and the average mortgage amount is approximately $\$ 280,000$. Finally, between 2005 and 2015, people in these ZIP codes spent an average of $\$ 18,200$ per year on their credit cards. 
In Panel $\mathrm{C}$ of Table 1, we divide the ZIP codes into two groups based on whether they had at least one IPO (column 1), or no IPOs (column 2) in a given year, and present the group averages in the prior year. On average, for every treated ZIP code-year with at least one IPO, we have five similar ZIP codes in the same county-year as controls. This table shows that we have a balanced set of treated and control ZIP codes. In the third column, we show univariate differences between ZIP codes with IPO activity and no IPO activity. In the last column, we express these differences normalized by their standard deviation. All of these normalized differences are close to 0 , suggesting good covariate balance.

\section{Empirical Results}

In our empirical analysis, we focus on estimating cross-sectional differences in the real estate and business development of ZIP codes within a given countyyear as a function of their distance from the ZIP code of the IPO headquarters.

\section{A. IPO Activity and Local Real Estate Markets}

Motivated by numerous articles about the IPO effects in the popular press, we begin our analysis by studying whether an IPO has an important effect on local real estate markets. The average number of homes sold in a ZIP code in a given year is fewer than 1,200, and the median firm in our sample has approximately 600 employees in the year it goes public. Therefore, if the change in the listing status of the company is an important liquidity event for its shareholders and employees, we expect this shock to have a significant effect on demand for the local housing market, even if just a fraction of the employees buy new homes.

Our empirical design allows us to estimate not only the magnitude, but also the geographic scope of IPO spillover effects on neighboring economies. Regression 1 in Table 2 suggests that an IPO does not significantly affect prices of houses for that ZIP code. However, neighborhoods adjacent to the IPO ZIP code, within a 2-mile range (WITHIN_2_MILES_FROM_IPO_HQ), experience an increase in home price growth 31 basis points (bps) larger than the mean (3.2\%). The difference in home price growth in ZIP codes that are farther away (between 2-5 or 5-10 miles) is indistinguishable from the average ZIP code home price growth in that county. The finding that post-IPO home price growth in the ZIP code of the IPO headquarters is similar to the average home price growth in the county suggests that our results are not driven by selection bias of the IPO ZIP code.

We hypothesize that larger IPOs may have larger effects on home prices, other things equal. Consistent with this hypothesis, we find that the magnitude of the effect of IPO activity in the top quartile of the yearly distribution on home price growth is larger and geographically more extensive. In column 2 of Table 2, home price growth in neighborhoods within a 2-mile radius of the IPO ZIP code increases by 88 bps more than it would without the IPO. Home prices in the ZIP codes in our sample grow at a rate of $3.2 \%$ per year. Therefore, a 31 - to 88 basis-point increase in home price growth is economically large and represents a $10 \%-28 \%$ increase over the mean.

The geographic reach of the spillover effect is also large. Not only do home prices within 2 miles of the IPO firm's headquarters increase, but we find that 
TABLE 2

Regressions of Home Price Growth on ZIP Code Distances from an IPO

In Table 2, the dependent variable is the average yearly growth rate of the home price index in the 2 -year period after an IPO in the ZIP code (source: Federal Housing Finance Agency). A coefficient of 1 indicates a $1 \%$ change in the dependent variable. IPO_HQ_ZIP_CODE is a dummy variable indicating if the headquarters (HQ) of the IPO firm is in that ZIP code. LARGE IPO HQ ZIP CODE is a dummy variable that indicates if the headquarters of the IPO firm is in that ZIP code and its proceeds are in the top quartile of the yearly distribution of proceeds. The IPO proximity variables indicate ZIP codes with no IPO activity in that year but are between either 0 and 2, 2 and 5, or 5 and 10 miles away from the closest ZIP code with at least one IPO in the same county-year. We control for SEO activity in the ZIP code and include the first lag of the dependent variable, the number of establishments, employment, ZIP code population, population density, and wage income. The regressions include county-year fixed effects. We cluster at the ZIP code and county-year level and report standard errors in parentheses. ${ }^{*},{ }^{* *}$, and ${ }^{* *}$ indicate significance at the $10 \%, 5 \%$, and $1 \%$ levels, respectively.

\begin{tabular}{|c|c|c|}
\hline & \multicolumn{2}{|c|}{ Home Price Index Growth } \\
\hline & 1 & 2 \\
\hline IPO_HQ_ZIP_CODE & $\begin{array}{c}0.052 \\
(0.121)\end{array}$ & \\
\hline$<0-2$ MILES_OF_IPO_HQ & $\begin{array}{c}0.311^{*} \\
(0.181)\end{array}$ & \\
\hline 2-5_MILES_FROM_IPO_HQ & $\begin{array}{c}0.168 \\
(0.112)\end{array}$ & \\
\hline 5-10_MILES_FROM_IPO_HQ & $\begin{array}{c}0.042 \\
(0.081)\end{array}$ & \\
\hline LARGE_IPO_HQ_ZIP_CODE & & $\begin{array}{c}0.083 \\
(0.154)\end{array}$ \\
\hline$<0-2$ MILES_FROM_LARGE_IPO_HQ & & $\begin{array}{l}0.884^{\star \star \star} \\
(0.241)\end{array}$ \\
\hline 2-5_MILES_FROM_LARGE_IPO_HQ & & $\begin{array}{l}0.649^{\star \star \star} \\
(0.153)\end{array}$ \\
\hline 5-10_MILES_FROM_LARGE_IPO_HQ & & $\begin{array}{c}0.151 \\
(0.093)\end{array}$ \\
\hline ZIP_SEO >0 & $\begin{array}{c}0.028 \\
(0.082)\end{array}$ & $\begin{array}{c}0.024 \\
(0.083)\end{array}$ \\
\hline LN(POPULATION) & $\begin{array}{c}-0.238^{\star \star \star} \\
(0.088)\end{array}$ & $\begin{array}{c}-0.221^{\star \star} \\
(0.092)\end{array}$ \\
\hline LN(ESTABLISHMENTS) & $\begin{array}{c}0.263 \\
(0.173)\end{array}$ & $\begin{array}{c}0.244 \\
(0.180)\end{array}$ \\
\hline LN(EMPLOYMENT) & $\begin{array}{c}0.042 \\
(0.102)\end{array}$ & $\begin{array}{c}0.032 \\
(0.104)\end{array}$ \\
\hline LN(WAGE_INCOME) & $\begin{array}{l}0.821^{\text {*ᄎ }} \\
(0.143)\end{array}$ & $\begin{array}{l}0.801^{\star \star \star} \\
(0.142)\end{array}$ \\
\hline LAGGED_DEPENDENT_VARIABLE & $\begin{array}{l}7.453^{\star \star \star} \\
(2.740)\end{array}$ & $\begin{array}{l}7.242^{\star \star \star} \\
(2.753)\end{array}$ \\
\hline POPULATION_DENSITY & 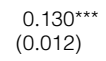 & $\begin{array}{l}0.123^{\star \star \star} \\
(0.012)\end{array}$ \\
\hline County-year fixed effects & Yes & Yes \\
\hline No. of obs. (ZIP-years) & 9,318 & 9,318 \\
\hline Adj. $R^{2}$ & 0.917 & 0.918 \\
\hline
\end{tabular}

home prices in ZIP codes 2-5 miles from the IPO firm's headquarters experience an increase in home price growth of $64 \mathrm{bps}$. Consistent with the hypothesis that the spillover effects gradually diminish for ZIP codes farther away from the location of the IPO, we find a modest and statistically insignificant increase in home prices for ZIP codes located more than 5 miles from the headquarters of the listed firm.

Finally, our results suggest that the change in home prices is because of the stock's listing, distinct from just raising capital. To separate these two hypotheses, we focus on SEOs because they resemble IPOs in terms of raising equity capital for the firm without involving a change in listing status. Even though the average equity proceeds from an SEO are approximately $47 \%$ larger than the proceeds of 
an average IPO, we do not find any evidence that SEOs have a direct impact on home prices.

If the increase in home prices we observe is due to the IPO, we suspect the effect should be more pronounced for expensive houses in the area. It is. In Table 3, we find evidence that IPOs have a positive impact on the price of expensive homes only. In column 3, we find that after an IPO, houses in a ZIP code that is centered within a 2-mile radius from the ZIP code of the IPO increase by $67 \mathrm{bps}$. This translates to an additional $\$ 3,900$ in the price for an expensive house (the average price is $\$ 590,000$ ). The IPO does not affect the prices of low- and

\section{TABLE 3}

\section{Regressions of Home Price Growth on ZIP Code Distances from an IPO}

In Table 3, the dependent variable is the average yearly growth rate of home values in the 2-year period after an IPO in the ZIP code (source: Zillow). A coefficient of 1 indicates a $1 \%$ change in the dependent variable. Bottom-, middle-, and top-tier houses in the lowest, middle, and top tercile of house prices in the ZIP code. IPO_HQ_ZIP_CODE is a dummy variable indicating if the headquarters $(\mathrm{HQ})$ of the IPO firm is in that ZIP code. LARGE IPO_HQ ZIP_CODE is a dummy variable that indicates if the headquarters of the IPO firm is in that ZIP code and its proceeds are in the top quartile of the yearly distribution of proceeds. The IPO proximity variables indicate ZIP codes with no IPO activity in that year but are between either 0 and 2,2 and 5, or 5 and 10 miles away from the closest ZIP code with at least one IPO in the same county-year. We control for SEO activity in the ZIP code and include the first lag of the dependent variable, the number of establishments, employment, ZIP code population, population density, and wage income. The regressions include county-year fixed effects. We cluster at the ZIP code and county-year level and report standard errors in parentheses. ${ }^{*},{ }^{* *}$, and ${ }^{* * *}$ indicate significance at the $10 \%, 5 \%$, and $1 \%$ levels, respectively

\begin{tabular}{|c|c|c|c|c|c|c|}
\hline & \multicolumn{3}{|c|}{ Home Price Growth: All IPOs } & \multicolumn{3}{|c|}{ Home Price Growth: Large IPOs } \\
\hline & Bottom-Tier & Middle-Tier & Top-Tier & Bottom-Tier & Middle-Tier & Top-Tier \\
\hline & 1 & 2 & 3 & 4 & 5 & 6 \\
\hline IPO_HQ_ZIP_CODE & $\begin{array}{r}-0.201 \\
(0.139)\end{array}$ & $\begin{array}{r}-0.068 \\
(0.137)\end{array}$ & $\begin{array}{c}0.092 \\
(0.141)\end{array}$ & & & \\
\hline 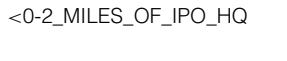 & $\begin{array}{c}0.014 \\
(0.242)\end{array}$ & $\begin{array}{c}0.082 \\
(0.224)\end{array}$ & $\begin{array}{l}0.674^{* * *} \\
(0.209)\end{array}$ & & & \\
\hline 2-5_MILES_FROM_IPO_HQ & $\begin{array}{r}-0.049 \\
(0.133)\end{array}$ & $\begin{array}{c}0.034 \\
(0.129)\end{array}$ & $\begin{array}{c}0.188 \\
(0.121)\end{array}$ & & & \\
\hline 5-10_MILES_FROM_IPO_HQ & $\begin{array}{r}-0.052 \\
(0.101)\end{array}$ & $\begin{array}{r}-0.053 \\
(0.010)\end{array}$ & $\begin{array}{c}0.053 \\
(0.095)\end{array}$ & & & \\
\hline LARGE_IPO_HQ_ZIP_CODE & & & & $\begin{array}{c}-0.158 \\
(0.232)\end{array}$ & $\begin{array}{r}-0.012 \\
(0.211)\end{array}$ & $\begin{array}{c}0.293 \\
(0.201)\end{array}$ \\
\hline $\begin{array}{l}<0-2 \text { _MILES_FROM_LARGE_ } \\
\text { IPO_HQ }\end{array}$ & & & & $\begin{array}{c}0.301 \\
(0.504)\end{array}$ & $\begin{array}{c}0.184 \\
(0.357)\end{array}$ & $\begin{array}{l}0.922^{\star \star \star} \\
(0.346)\end{array}$ \\
\hline $\begin{array}{l}\text { 2-5_MILES_FROM_LARGE_ } \\
\text { IPO_HQ }\end{array}$ & & & & $\begin{array}{c}0.225 \\
(0.210)\end{array}$ & $\begin{array}{l}0.363^{\star \star} \\
(0.158)\end{array}$ & $\begin{array}{l}0.649^{\star \star \star} \\
(0.171)\end{array}$ \\
\hline $\begin{array}{l}\text { 5-10_MILES_FROM_LARGE_ } \\
\text { IPO_HQ }\end{array}$ & & & & $\begin{array}{c}0.091 \\
(0.144)\end{array}$ & $\begin{array}{c}0.081 \\
(0.110)\end{array}$ & $\begin{array}{l}0.260^{\star \star} \\
(0.112)\end{array}$ \\
\hline ZIP_SEO $>0$ & $\begin{array}{c}-0.021 \\
(0.104)\end{array}$ & $\begin{array}{c}0.088 \\
(0.082)\end{array}$ & $\begin{array}{c}0.128 \\
(0.082)\end{array}$ & $\begin{array}{c}-0.022 \\
(0.104)\end{array}$ & $\begin{array}{c}0.080 \\
(0.078)\end{array}$ & $\begin{array}{c}0.123 \\
(0.091)\end{array}$ \\
\hline LN(POPULATION) & $\begin{array}{c}-0.124 \\
(0.132)\end{array}$ & $\begin{array}{c}-0.175 \\
(0.111)\end{array}$ & $\begin{array}{c}-0.152 \\
(0.092)\end{array}$ & $\begin{array}{c}-0.107 \\
(0.128)\end{array}$ & $\begin{array}{c}-0.167 \\
(0.113)\end{array}$ & $\begin{array}{c}-0.145 \\
(0.094)\end{array}$ \\
\hline LN(ESTABLISHMENTS) & $\begin{array}{c}0.145 \\
(0.202)\end{array}$ & $\begin{array}{c}0.233 \\
(0.181)\end{array}$ & $\begin{array}{l}0.453^{\star \star} \\
(0.180)\end{array}$ & $\begin{array}{c}0.142 \\
(0.198)\end{array}$ & $\begin{array}{c}0.224 \\
(0.185)\end{array}$ & $\begin{array}{l}0.434^{\star \star} \\
(0.184)\end{array}$ \\
\hline LN(EMPLOYMENT) & $\begin{array}{c}-0.014 \\
(0.121)\end{array}$ & $\begin{array}{c}-0.050 \\
(0.103)\end{array}$ & $\begin{array}{r}-0.141 \\
(0.099)\end{array}$ & $\begin{array}{c}-0.012 \\
(0.119)\end{array}$ & $\begin{array}{c}-0.054 \\
(0.102)\end{array}$ & $\begin{array}{r}-0.136 \\
(0.101)\end{array}$ \\
\hline LN(WAGE_INCOME) & $\begin{array}{l}0.815^{\star \star \star} \\
(0.192)\end{array}$ & $\begin{array}{l}0.802^{\star \star \star} \\
(0.211)\end{array}$ & $\begin{array}{c}0.153 \\
(0.181)\end{array}$ & $\begin{array}{l}0.802^{\star \star \star} \\
(0.191)\end{array}$ & $\begin{array}{l}0.794^{\star \star \star} \\
(0.209)\end{array}$ & $\begin{array}{c}0.149 \\
(0.178)\end{array}$ \\
\hline $\begin{array}{l}\text { LAGGED_DEPENDENT_ } \\
\text { VARIABLE }\end{array}$ & $\begin{array}{l}5.862^{\star \star} \\
(2.770)\end{array}$ & $\begin{array}{l}6.552^{\star \star} \\
(3.181)\end{array}$ & $\begin{array}{l}9.653^{\star \star \star} \\
(3.178)\end{array}$ & $\begin{array}{l}5.824^{\star \star} \\
(2.784)\end{array}$ & $\begin{array}{l}6.441^{\star \star} \\
(3.192)\end{array}$ & $\begin{array}{l}9.501^{\star \star \star} \\
(3.187)\end{array}$ \\
\hline POPULATION_DENSITY & $\begin{array}{l}0.093^{\star \star \star} \\
(0.022)\end{array}$ & $\begin{array}{l}0.092^{\star \star \star} \\
(0.022)\end{array}$ & $\begin{array}{l}0.109^{\star \star \star} \\
(0.015)\end{array}$ & $\begin{array}{l}0.093^{\star \star \star} \\
(0.017)\end{array}$ & $\begin{array}{l}0.094^{\star \star \star} \\
(0.023)\end{array}$ & $\begin{array}{l}0.106^{\star \star \star} \\
(0.021)\end{array}$ \\
\hline County-year fixed effects & Yes & Yes & Yes & Yes & Yes & Yes \\
\hline $\begin{array}{l}\text { No. of obs. (ZIP-years) } \\
\text { Adi } R^{2}\end{array}$ & $\begin{array}{l}7,577 \\
0,920\end{array}$ & $\begin{array}{r}7,831 \\
0,927\end{array}$ & 7,784 & 7,577 & 7,831 & 7,784 \\
\hline Adj. $R^{2}$ & 0.920 & 0.927 & 0.918 & 0.920 & 0.927 & 0.918 \\
\hline
\end{tabular}


mid-tier homes within 0 to 2 miles. The geographic reach of large IPOs (top quartile of proceeds in that year) is extensive; the value of expensive homes increases by 92 bps $(\$ 5,400)$ if located within 2 miles of the IPO, or 65 bps $(\$ 3,800)$ if located between 2 and 5 miles. Even though we find that IPOs have a significant impact on local real estate markets, we do not find evidence that they affect home prices in the IPO headquarters' ZIP code.

The increase in demand for housing in neighborhoods close to a newly listed firm should also lead to an increase in demand for mortgages to finance those homes. $^{7}$ To test this hypothesis, we calculate the growth in the number of mortgage applications, the total mortgage amount, and the average mortgage amount in ZIP codes close to the IPO firm's headquarters. The results in Table 4 show that

TABLE 4

Regressions of Mortgage Origination Growth on ZIP Code Distances from an IPO

In column 1 of Table 4, the dependent variable is the yearly growth of average mortgage amount, defined as the total mortgage amounts in the ZIP code divided by the number of accepted applications. In column 2, the dependent variable is the growth of total mortgage amounts in the ZIP code. In column 3 , the dependent variable is the growth in the total number of accepted mortgage applications in the ZIP code. Growth rates are over the 2-year period after an IPO in the ZIP code. A coefficient of 1 indicates a 1\% change in the dependent variable. LARGE_IPO HQ_ZIP_CODE is a dummy variable that indicates if the headquarters of the IPO firm is in that ZIP code and its proceeds are in the top quartile of the yearly distribution of proceeds. The IPO proximity variables indicate ZIP codes with no IPO activity in that year but are between either 0 and 2, 2 and 5, or 5 and 10 miles away from the closest ZIP code with at least one IPO in the same county-year. We control for SEO activity in the ZIP code and include the first lag of the dependent variable, the number of establishments, employment, ZIP code population, population density, and wage income. The regressions include county-year fixed effects. We cluster at the ZIP code and county-year level and report standard errors in parentheses. ${ }^{*}, * *$, and ${ }^{* \star *}$ indicate significance at the $10 \%, 5 \%$, and $1 \%$ levels, respectively.

\begin{tabular}{|c|c|c|c|}
\hline & $\begin{array}{l}\text { Avg. Mortgage } \\
\text { Amount } \\
\text { Growth } \\
1\end{array}$ & $\begin{array}{l}\text { Total Mortgage } \\
\text { Amount } \\
\text { Growth } \\
2\end{array}$ & $\begin{array}{c}\text { Mortgage } \\
\text { Applications } \\
\text { Growth } \\
3\end{array}$ \\
\hline LARGE_IPO_HQ_ZIP_CODE & $\begin{array}{l}1.147^{* *} \\
(0.501)\end{array}$ & $\begin{array}{c}1.119 \\
(1.657)\end{array}$ & $\begin{array}{c}-0.132 \\
(1.391)\end{array}$ \\
\hline 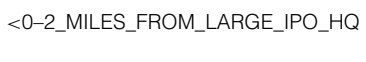 & $\begin{array}{l}1.333^{* *} \\
(0.582)\end{array}$ & $\begin{array}{r}4.055^{*} \\
(2.321)\end{array}$ & $\begin{array}{l}2.800 \\
(2.019)\end{array}$ \\
\hline 2-5_MILES_FROM_LARGE_IPO_HQ & $\begin{array}{l}0.774^{\star *} \\
(0.331)\end{array}$ & $\begin{array}{l}2.449^{\star \star} \\
(1.168)\end{array}$ & $\begin{aligned} & 1.884^{*} \\
&(1.007)\end{aligned}$ \\
\hline 5-10_MILES_FROM_LARGE_IPO_HQ & $\begin{array}{l}0.598^{* *} \\
(0.292)\end{array}$ & $\begin{array}{c}0.289 \\
(0.778)\end{array}$ & $\begin{array}{c}-0.132 \\
(0.674)\end{array}$ \\
\hline ZIP_SEO>0 & $\begin{array}{c}-0.229 \\
(0.177)\end{array}$ & $\begin{array}{l}-0.467 \\
(0.542)\end{array}$ & $\begin{array}{c}-0.439 \\
(0.472)\end{array}$ \\
\hline LN(POPULATION) & $\begin{array}{r}-0.302^{*} \\
(0.167)\end{array}$ & $\begin{array}{c}-0.789 \\
(0.641)\end{array}$ & $\begin{array}{c}-0.305 \\
(0.536)\end{array}$ \\
\hline LN(ESTABLISHMENTS) & $\begin{array}{c}0.632^{*} \\
(0.321)\end{array}$ & $\begin{array}{c}0.523 \\
(1.312)\end{array}$ & $\begin{array}{c}0.189 \\
(1.178)\end{array}$ \\
\hline LN(EMPLOYMENT) & $\begin{array}{c}-0.154 \\
(0.223)\end{array}$ & $\begin{array}{l}-0.120 \\
(0.801)\end{array}$ & $\begin{array}{l}-0.256 \\
(0.709)\end{array}$ \\
\hline LN(WAGE_INCOME) & $\begin{array}{l}-2.443^{\star * \star} \\
(0.844)\end{array}$ & $\begin{array}{r}4.244^{*} \\
(2.456)\end{array}$ & $\begin{array}{l}4.634^{\star *} \\
(2.218)\end{array}$ \\
\hline LAGGED_DEPENDENT_VARIABLE & $\begin{array}{c}-43.482^{\star \star *} \\
(2.064)\end{array}$ & $\begin{array}{c}-42.925^{\star \star *} \\
(4.663)\end{array}$ & $\begin{array}{c}-40.390^{* * *} \\
(4.514)\end{array}$ \\
\hline POPULATION_DENSITY & $\begin{array}{l}0.184^{\star \star \star} \\
(0.028)\end{array}$ & $\begin{array}{r}0.211^{*} \\
(0.111)\end{array}$ & $\begin{array}{c}0.053 \\
(0.094)\end{array}$ \\
\hline County-year fixed effects & Yes & Yes & Yes \\
\hline $\begin{array}{l}\text { No. of obs. (ZIP-years) } \\
\text { Adj. } R^{2}\end{array}$ & $\begin{array}{l}7,421 \\
0.506\end{array}$ & $\begin{array}{l}7,421 \\
0.784\end{array}$ & $\begin{array}{l}7,421 \\
0.799\end{array}$ \\
\hline
\end{tabular}

${ }^{7}$ Even Mark Zuckerberg, the CEO of Facebook, refinanced his $\$ 5.95$ million mortgage after the IPO for his house located 3 miles from Facebook's headquarters (https://www.cnbc.com/id/ 48220824). 
an IPO leads to a $0.6 \%-1.3 \%(\$ 1,700-\$ 3,700)$ increase in the average mortgage amount for new mortgages. Taken together, the evidence in this section suggests that IPO activity has a meaningful effect on local housing markets.

\section{B. IPO Activity, Local Employment, and Local Business Development}

The large effect of IPO activity on local housing markets suggests that IPOs most likely have a broader effect on local economies. Recent literature suggests that houses, which can be used as collateral, affect local employment and business development by easing financial constraints. In two recent papers, researchers show the effect of house prices on employment. Schmalz et al. (2017) show that an $11 \%$ increase in home prices in France is associated with a $4 \%$ increase in employment for firms in their sample. Mian and Sufi (2014) show that counties with the largest home price declines during the financial crisis experience the largest decrease in employment. Adelino et al. (2015) show that Metropolitan Statistical Areas with the highest increase in home prices during the 2002-2007 housing boom experienced a larger increase in establishment growth. Babina et al. (2017) find a positive association between IPO activity and subsequent firm creation by employees who move to startup companies.

We test whether IPO activity is associated with increases in local employment and business establishments. We start by regressing employment growth and establishment growth of a ZIP code on its proximity to an IPO. The results in columns 1 and 2 in Table 5 suggest that IPOs have a positive impact on the employment growth in the ZIP code of the IPO headquarters. The effect is economically large: Employers create roughly 150-190 new jobs per year (an increase of 65 bps-78 bps) close to the firm's headquarters. This result is consistent with Kenney et al. (2012), who find that post-IPO firm employment increases by approximately 200 people per year. However, the IPO firm is unlikely to be responsible for all of the increase in local employment growth. Large firms also have employees outside their headquarters, suggesting that the IPO firm is not responsible for all of the 190 additional employees in the ZIP code, as we find. According to Borisov, Ellul, and Sevilir (2017), the causal effect of an IPO on firm employment (compared to similar firms that do not go public) is approximately 50 new employees. Taken together, these results suggest that although the IPO firm contributes significantly to the ZIP code's abnormal increase in employment, a significant portion comes from IPO spillovers. ${ }^{8}$

An IPO's effect on the local growth of employment or new businesses could be because the new businesses support the newly listed IPO firm or because they support people who live nearby. Growth of establishments in the tradable sector more likely reflects a response to the IPO firm and its growth. Local demand from individual people is more likely to affect the growth of establishments in the retail sector (nontradable), such as restaurants or in construction. We classify the tradable, nontradable, and construction sectors as Mian and Sufi (2014) do, and

\footnotetext{
${ }^{8}$ When we exclude spinoffs from our sample, employment also grows in nearby ZIP codes. In terms of numbers, in ZIP codes 0-2 miles from the ground-zero ZIP code where the IPO firm's headquarters is, employment growth is on average $60 \mathrm{bps}$ or, roughly, an additional 148 people when we aggregate over all ZIP codes in that distance for the nonspinoff sample. We argue this employment increase is coming from outside the IPO firm.
} 
TABLE 5

OLS Regressions of Employment Growth on ZIP Code Distances from an IPO

In Table 5, the dependent variable is the average yearly growth rates of employment in the 2-year period after an IPO in the ZIP code. A coefficient of 1 indicates a $1 \%$ change in the dependent variable. IPO_HQ_ZIP_CODE is a dummy variable indicating if the headquarters $(\mathrm{HQ})$ of the IPO firm is in that ZIP code. LARGE_IPO_HQ_ZIP_CODE is a dummy variable that indicates if the headquarters of the IPO firm is in that ZIP code, and its proceeds are in the top quartile of the yearly distribution of proceeds. The IPO proximity variables indicate ZIP codes with no IPO activity in that year but are between either 0 and 2, 2 and 5, or 5 and 10 miles away from the closest ZIP code with at least one IPO in the same county-year. We control for SEO activity in the ZIP code and include the first lag of the dependent variable, ZIP code population, population density, establishments, and wage income. All regressions include county-year fixed effects. We cluster at the ZIP code and county-year level and report standard errors in parentheses. *, **, and *** indicate significance at the $10 \%, 5 \%$, and $1 \%$ levels, respectively.

\begin{tabular}{|c|c|c|}
\hline & \multicolumn{2}{|c|}{ Employment Growth } \\
\hline & 1 & 2 \\
\hline IPO_HQ_ZIP_CODE & $\begin{array}{l}0.651^{\star \star} \\
(0.321)\end{array}$ & \\
\hline$<0-2$ _MILES_OF_IPO_HQ & $\begin{array}{c}-0.056 \\
(0.377)\end{array}$ & \\
\hline 2-5_MILES_FROM_IPO_HQ & $\begin{array}{r}-0.190 \\
(0.219)\end{array}$ & \\
\hline 5-10_MILES_FROM_IPO_HQ & $\begin{array}{r}-0.041 \\
(0.191)\end{array}$ & \\
\hline LARGE_IPO_HQ_ZIP_CODE & & $\begin{array}{c}0.784^{\star} \\
(0.437)\end{array}$ \\
\hline$<0-2$ _MILES_FROM_LARGE_IPO_HQ & & $\begin{array}{c}0.598 \\
(0.701)\end{array}$ \\
\hline 2-5_MILES_FROM_LARGE_IPO_HQ & & $\begin{array}{c}0.184 \\
(0.358)\end{array}$ \\
\hline 5-10_MILES_FROM_LARGE_IPO_HQ & & $\begin{array}{c}0.279 \\
(0.261)\end{array}$ \\
\hline ZIP_SEO>0 & $\begin{array}{c}0.101 \\
(0.235)\end{array}$ & $\begin{array}{c}0.130 \\
(0.241)\end{array}$ \\
\hline LN(POPULATION) & $\begin{array}{c}0.036 \\
(0.182)\end{array}$ & $\begin{array}{c}0.053 \\
(0.168)\end{array}$ \\
\hline LN(ESTABLISHMENTS) & $\begin{array}{c}-1.184^{\star \star \star} \\
(0.191)\end{array}$ & $\begin{array}{c}-1.171^{\star \star \star} \\
(0.180)\end{array}$ \\
\hline LN(WAGE_INCOME) & $\begin{array}{l}1.107^{\star \star \star} \\
(0.215)\end{array}$ & $\begin{array}{l}1.084^{\star \star \star} \\
(0.234)\end{array}$ \\
\hline LAGGED_DEPENDENT_VARIABLE & $\begin{array}{r}-1.032 \\
(2.552)\end{array}$ & $\begin{array}{c}-0.918 \\
(2.559)\end{array}$ \\
\hline POPULATION_DENSITY & $\begin{array}{c}-0.054^{\star \star \star} \\
(0.021)\end{array}$ & $\begin{array}{c}-0.061^{\star \star \star} \\
(0.020)\end{array}$ \\
\hline County-year fixed effects & Yes & Yes \\
\hline $\begin{array}{l}\text { No. of obs. (ZIP-years) } \\
\text { Adj. } R^{2}\end{array}$ & $\begin{array}{l}9,284 \\
0.162\end{array}$ & $\begin{array}{l}9,284 \\
0.161\end{array}$ \\
\hline
\end{tabular}

calculate the change in the total number of establishments of each sector. The results in Table 6 suggest that IPO activity has a large positive effect on nontradable business establishments and construction (those that likely serve demand from individual people), but the effect of the IPO on the local growth of tradable sector establishments (those that might support business operations), is indistinguishable from 0 .

Our results are consistent with previous studies that find significant spillover effects from manufacturing plant openings or closures. For instance, Bernstein, Colonnelli, Giroud, and Iverson (2019) find that corporate bankruptcies have a negative spillover effect on local employment, especially in the nontradable sector and services. Large industrial plants have a positive effect on local economic development and productivity, despite the size of government subsidies to attract 
TABLE 6

Regressions of Establishment Growth (by Trade Sector) on ZIP Code Distances from an IPO

In Table 6 , the dependent variables are, respectively, the average yearly growth rates of establishments in the 2 -year period after an IPO in the ZIP code (source: Census ZIP code business patterns). A coefficient of 1 indicates a $1 \%$ change in the dependent variable. We calculate the number of establishments in the tradable, nontradable, and construction sectors using their NAICS codes following Mian and Sufi (2014) (see Supplementary Material Table A.VI). IPO_HQ_ZIP_CODE is a dummy variable indicating if the headquarters (HQ) of the IPO firm is in that ZIP code. The IPO proximity variables indicate ZIP codes with no IPO activity in that year but are between either 0 and 2, 2 and 5 , or 5 and 10 miles away from the closest ZIP code with at least one IPO in the same county-year. We control for SEO activity in the ZIP code and include the first lag of the dependent variable, the number of establishments, employment, ZIP code population, population density, and wage income. The regressions include county-year fixed effects. We cluster at the ZIP code and county-year level and report standard errors in parentheses. ${ }^{*},{ }^{* *}$, and ${ }^{\star * *}$ indicate significance at the $10 \%, 5 \%$, and $1 \%$ levels, respectively.

\begin{tabular}{|c|c|c|c|}
\hline & \multicolumn{3}{|c|}{ Establishments Growth } \\
\hline & $\begin{array}{c}\text { Tradable } \\
\text { Sector }\end{array}$ & $\begin{array}{c}\text { Nontradable } \\
\text { Sector }\end{array}$ & Construction \\
\hline & 1 & 2 & 3 \\
\hline IPO_HQ_ZIP_CODE & $\begin{array}{c}-0.182 \\
(0.284)\end{array}$ & $\begin{array}{c}0.274 \\
(0.219)\end{array}$ & $\begin{array}{l}0.574^{\star *} \\
(0.240)\end{array}$ \\
\hline$<0-2$ _MILES_OF_IPO_HQ & $\begin{array}{c}0.110 \\
(0.671)\end{array}$ & $\begin{array}{l}0.824^{\text {***}} \\
(0.261)\end{array}$ & $\begin{array}{c}0.134 \\
(0.367)\end{array}$ \\
\hline 2-5_MILES_FROM_IPO_HQ & $\begin{array}{c}-0.289 \\
(0.371)\end{array}$ & $\begin{array}{c}-0.150 \\
(0.122)\end{array}$ & $\begin{array}{c}-0.012 \\
(0.389)\end{array}$ \\
\hline 5-10_MILES_FROM_IPO_HQ & $\begin{array}{r}-0.030 \\
(0.432)\end{array}$ & $\begin{array}{c}-0.025 \\
(0.204)\end{array}$ & $\begin{array}{l}0.602^{* * *} \\
(0.190)\end{array}$ \\
\hline ZIP_SEO >0 & $\begin{array}{c}0.177 \\
(0.506)\end{array}$ & $\begin{array}{c}0.501 \\
(0.302)\end{array}$ & $\begin{array}{c}0.431 \\
(0.279)\end{array}$ \\
\hline LN(POPULATION) & $\begin{array}{c}0.454 \\
(0.329)\end{array}$ & $\begin{array}{c}0.022 \\
(0.188)\end{array}$ & $\begin{array}{r}-0.162 \\
(0.284)\end{array}$ \\
\hline LN(ESTABLISHMENTS) & $\begin{array}{c}-1.956^{\star *} \\
(0.785)\end{array}$ & $\begin{array}{c}-1.494^{\text {** }} \\
(0.631)\end{array}$ & $\begin{array}{c}-1.671^{\star \star *} \\
(0.372)\end{array}$ \\
\hline LN(EMPLOYMENT) & $\begin{array}{l}1.754^{\star *} \\
(0.654)\end{array}$ & $\begin{array}{c}0.412 \\
(0.310)\end{array}$ & $\begin{array}{c}0.714 \\
(0.516)\end{array}$ \\
\hline LN(WAGE_INCOME) & $\begin{array}{l}1.401^{\star \star \star} \\
(0.360)\end{array}$ & $\begin{array}{l}0.757^{\star *} \\
(0.246)\end{array}$ & $\begin{array}{c}0.383 \\
(0.376)\end{array}$ \\
\hline LAGGED_DEPENDENT_VARIABLE & $\begin{array}{c}-18.580^{\star \star *} \\
(3.271)\end{array}$ & $\begin{array}{c}0.810 \\
(2.429)\end{array}$ & $\begin{array}{c}-21.011^{* * *} \\
(2.791)\end{array}$ \\
\hline POPULATION_DENSITY & $\begin{array}{r}-0.142^{*} \\
(0.067)\end{array}$ & $\begin{array}{c}-0.014 \\
(0.032)\end{array}$ & $\begin{array}{c}-0.062 \\
(0.044)\end{array}$ \\
\hline County-year fixed effects & Yes & Yes & Yes \\
\hline $\begin{array}{l}\text { No. of obs. (ZIP-years) } \\
\text { Adj. } R^{2}\end{array}$ & $\begin{array}{l}8,411 \\
0.055\end{array}$ & $\begin{array}{l}8,586 \\
0.114\end{array}$ & $\begin{array}{l}8,587 \\
0.224\end{array}$ \\
\hline
\end{tabular}

investment (see Greenstone and Moretti (2003), Greenstone, Hornbeck, and Moretti (2010)). Moretti (2010) estimates that for each additional job in manufacturing (skilled professions), there are 1.6-2.5 new jobs in the nontradable sector. More studies report similar estimates from other public expenditures, such as building NFL stadiums (Carlino and Coulson (2004)) or sponsoring the Olympic games (Kavetsos (2012)).

We, too, find spillover effects, but we view our contribution as inherently distinct from the above. Opening or closing manufacturing plants, stadia, or other establishments reflects direct investment (or disinvestment) and employment in the local economies. However, the change in listing status we study is a financial transformation that does not involve the creation (or dissolution) of a new (existing) company. In this sense, our study relates more to the debate on whether equity markets are a sideshow (Morck, Shleifer, Vishny, Shapiro, and Poterba (1990) suggests they are not). 
Mian et al. (2013) find a strong positive relation between changes in housing net worth and consumption. Using Experian data on credit card spending, we show that IPOs affect local consumer demand. In Table 7, we regress credit card spending growth on each ZIP code's proximity to an IPO. The results in columns 1 and 2 suggest that, even though credit card spending does not increase in ZIP codes where IPOs take place, ZIP codes within 2 miles and within 2-5 miles experience a large increase in spending. The increase in spending is not trivial; growth of credit card spending increases by $1.3 \%$ to $3.6 \%$, which is equivalent to a $10 \%$ to $26 \%$ increase in the average annual growth, or $\$ 240$ to $\$ 640$ in spending per year.

\section{TABLE 7}

Regressions of Credit Card Spending Growth on ZIP Code Distances from an IPO

In Table 7, the dependent variable is the average yearly growth rate of credit card spending in the 2-year period after an IPO. A coefficient of 1 indicates a $1 \%$ change in the dependent variable. We construct ZIP code spending growth data from a large sample of people who live in the ZIP code (source: Experian). IPO_HQ_ZIP_CODE is a dummy variable indicating if the headquarters $(\mathrm{HQ})$ of the IPO firm is in that ZIP code. LARGE_IPO_HQ_ZIP_CODE is a dummy variable that indicates if the headquarters of the IPO firm is in that ZIP code, and its proceeds are in the top quartile of the yearly distribution of proceeds. The IPO proximity variables indicate ZIP codes with no IPO activity in that year but are between either 0 and 2,2 and 5, or 5 and 10 miles away from the closest ZIP code with at least one IPO in the same county-year. We control for SEO activity in the ZIP code and include the first lag of the dependent variable, the number of establishments, employment, ZIP code population, population density, and wage income. The regressions include county-year fixed effects. We cluster at the ZIP code and county-year level and report standard errors in parentheses. ${ }^{*},{ }^{* *}$, and ${ }^{* * *}$ indicate significance at the $10 \%, 5 \%$, and $1 \%$ levels, respectively.

\begin{tabular}{|c|c|c|}
\hline & \multicolumn{2}{|c|}{ Credit Card Spending Growth } \\
\hline & 1 & 2 \\
\hline IPO_HQ_ZIP_CODE & $\begin{array}{r}-1.077 \\
(0.811)\end{array}$ & \\
\hline$<0-2$ _MILES_OF_IPO_HQ & $\begin{array}{l}3.071^{\star \star \star} \\
(1.069)\end{array}$ & \\
\hline 2-5_MILES_FROM_IPO_HQ & $\begin{array}{l}1.368^{\star \star} \\
(0.651)\end{array}$ & \\
\hline 5-10_MILES_FROM_IPO_HQ & $\begin{array}{c}0.194 \\
(0.560)\end{array}$ & \\
\hline LARGE_IPO_HQ_ZIP_CODE & & $\begin{array}{c}0.473 \\
(1.224)\end{array}$ \\
\hline$<0-2$ MILES_FROM_LARGE_IPO_HQ & & $\begin{array}{l}3.214^{\star} \\
(1.801)\end{array}$ \\
\hline 2-5_MILES_FROM_LARGE_IPO_HQ & & $\begin{array}{l}3.561^{\star \star \star} \\
(1.117)\end{array}$ \\
\hline 5-10_MILES_FROM_LARGE_IPO_HQ & & $\begin{array}{r}1.763^{\star} \\
(1.010)\end{array}$ \\
\hline ZIP_SEO >0 & $\begin{array}{c}0.004 \\
(0.679)\end{array}$ & $\begin{array}{c}-0.214 \\
(0.682)\end{array}$ \\
\hline LN(POPULATION) & $\begin{array}{l}-1.042^{\star \star} \\
(0.499)\end{array}$ & $\begin{array}{l}-1.101^{\star \star} \\
(0.481)\end{array}$ \\
\hline LN(ESTABLISHMENTS) & $\begin{array}{l}3.420^{\star \star \star} \\
(1.171)\end{array}$ & $\begin{array}{l}3.336^{\star \star \star} \\
(1.142)\end{array}$ \\
\hline LN(EMPLOYMENT) & $\begin{array}{r}-0.980 \\
(0.810)\end{array}$ & $\begin{array}{r}-1.072 \\
(0.811)\end{array}$ \\
\hline LN(WAGE_INCOME) & $\begin{array}{l}9.178^{\star \star \star} \\
(1.084)\end{array}$ & $\begin{array}{l}9.130^{\star \star \star} \\
(1.065)\end{array}$ \\
\hline LAGGED_DEPENDENT_VARIABLE & $\begin{array}{l}-27.261^{\star \star \star} \\
(1.741)\end{array}$ & $\begin{array}{l}-27.421^{\star \star \star} \\
(1.729)\end{array}$ \\
\hline POPULATION_DENSITY & $\begin{array}{l}0.345^{\star \star \star} \\
(0.094)\end{array}$ & $\begin{array}{l}0.343^{\star \star \star} \\
(0.093)\end{array}$ \\
\hline County-year fixed effects & Yes & Yes \\
\hline $\begin{array}{l}\text { No. of obs. (ZIP-years) } \\
\text { Adj. } R^{2}\end{array}$ & $\begin{array}{l}3,729 \\
0.614\end{array}$ & $\begin{array}{l}3,729 \\
0.614\end{array}$ \\
\hline
\end{tabular}




\section{Liquidity and Wealth Effects of IPOs}

The change in the listing status of the firm is a significant market liquidity event for the employees and shareholders of a firm. After the change in its listing status, however, fluctuations in the stock price of the firm also affect the wealth of its employees and early investors. We test whether changes in liquidity, changes in wealth, or changes in both factors are associated with an IPO spillover effect.

To test this hypothesis, we exploit the heterogeneity of the characteristics of an IPO. To identify a liquidity effect from an IPO, we exploit the timing of the expiration of the lock-up period, allowing investors to sell their shares. If changes in investor liquidity cause the spillover effects, the effect should be larger after the lockup period expires. If investor wealth causes the spillover effects, an increase in the firm's stock price above its offer price should also have a significant effect on the local economy.

There are important technical challenges in testing these hypotheses empirically. Most IPOs have a 6-month lockup period, but 3- or 9-month or staggered lockup periods are not rare. To exploit the timing of the lockup expiration, we need an outcome variable that is measured at a granular time-series frequency. Zillow's monthly data on ZIP code level home prices satisfy this requirement. We construct a dependent variable that measures the abnormal house price growth close to each IPO firm's headquarters. Specifically, we calculate the difference in the monthly average home price growth of ZIP codes within 5 miles of the IPO headquarters and ZIP codes between 5 and 20 miles of the IPO headquarters.

The treatment effect in this sample comes from the IPO timing and the timing of the expiration of the lockup. We define four time periods: the first period, before the IPO filing date, serves as our control period; the second (POST_FILING_DATE) is a dummy variable that equals 1 for months after the IPO filing date, and 0 otherwise; the third (POST ISSUE_DATE) is a dummy that equals 1 for months after the first trading date, and 0 otherwise; the fourth (POST_LOCKUP) is a dummy that equals 1 for months after the lockup expiration, and 0 otherwise. We collapse the time-series information of the monthly differences in home price growth into these four periods to address the issue that differences-in-differences regressions tend to over-reject the null of no effect, especially when the outcome variables are serially correlated (Bertrand, Duflo, and Mullainathan (2004)).

In Table 8, the dependent variable is the difference in average top-tier home price growth in ZIP codes located within 5 miles of the IPO headquarters' ZIP code from that of ZIP codes between 5 and 20 miles of the IPO headquarters (the control). The results in column 1 suggest that after the IPO filing date, prices in ZIP codes within 5 miles of the IPO headquarters' ZIP code increase by an additional 5 bps per month ( 60 bps annually) compared to ZIP codes in the same county and year located between 5 and 20 miles from the IPO headquarters. Consistent with the hypothesis that investor liquidity causes IPO spillover effects, home price growth increases by 5 bps per month after the expiration of the lockup period.

To test the hypothesis that changes in investors' wealth drive the change in spillover effects, we identify firms whose stock price in the 12-month period after 
TABLE 8

Investor Liquidity versus Investor Wealth

In Table 8, the dependent variable is the difference in home price (top-tier) growth per month of ZIP codes within a 5-mile IPO-range and the home price growth of ZIP codes within a 5 to 20 mile IPO-range in a given county-year. A coefficient of 1 indicates a 1\% change in the dependent variable. POST_FILING_DATE is a dummy that equals 1 if the date is greater than the IPO filing date, and 0 otherwise. POST_ISSUE_DATE (POST_LOCKUP) is a dummy that equals 1 if the date is greater than the lockup expiration. PRICE_INCREASE is a dummy that equals 1 if the (12-month) average stock market price is above the offer price. BUYOUT_IPO is a dummy that equals 1 if the IPO was buyout-backed. We include as controls the natural log the following ZIP code control variables: population, population density, establishments, employment, and wage income. All regressions include industry (2-digit Standard Industrial Classification (SIC2) codes) and year fixed effects. We cluster at industry (SIC2) and year and report robust standard errors in parentheses. ${ }^{*}$,**, and ${ }^{* * *}$ indicate significance at the $10 \%, 5 \%$, and $1 \%$ levels, respectively.

Top-Tier Home Price Growth

\begin{tabular}{|c|c|c|c|}
\hline POST_FILING_DATE & $\begin{array}{l}0.052^{\star *} \\
(0.023)\end{array}$ & $\begin{array}{l}0.053^{\star *} \\
(0.022)\end{array}$ & $\begin{array}{l}0.053^{\star \star} \\
(0.021)\end{array}$ \\
\hline POST_ISSUE_DATE & $\begin{array}{c}0.013 \\
(0.023)\end{array}$ & $\begin{array}{c}-0.028 \\
(0.031)\end{array}$ & $\begin{array}{c}0.011 \\
(0.019)\end{array}$ \\
\hline POST_LOCKUP & $\begin{array}{l}0.049^{* * *} \\
(0.019)\end{array}$ & $\begin{array}{r}0.044^{*} \\
(0.023)\end{array}$ & $\begin{array}{l}0.058^{\star \star \star} \\
(0.021)\end{array}$ \\
\hline PRICE_INCREASE & & $\begin{array}{c}0.003 \\
(0.021)\end{array}$ & \\
\hline POST_ISSUE $\times$ PRICE_INCREASE & & $\begin{array}{c}0.024 \\
(0.029)\end{array}$ & \\
\hline POST_LOCKUP $\times$ PRICE_INCREASE & & $\begin{array}{l}0.081^{* *} \\
(0.034)\end{array}$ & \\
\hline BUYOUT_IPO & & & $\begin{array}{c}0.022 \\
(0.054)\end{array}$ \\
\hline POST_FILING_DATE $\times$ BUYOUT_IPO & & & $\begin{array}{c}-0.045^{\star \star} \\
(0.021)\end{array}$ \\
\hline POST_ISSUE $\times$ BUYOUT_IPO & & & $\begin{array}{c}0.030 \\
(0.068)\end{array}$ \\
\hline POST_LOCKUP $\times$ BUYOUT_IPO & & & $\begin{array}{c}-0.041 \\
(0.030)\end{array}$ \\
\hline LN(POPULATION) & $\begin{array}{l}-0.032^{* * *} \\
(0.010)\end{array}$ & $\begin{array}{l}-0.033^{* * *} \\
(0.011)\end{array}$ & $\begin{array}{l}-0.031^{\star \star \star} \\
(0.010)\end{array}$ \\
\hline LN(ESTABLISHMENTS) & $\begin{array}{c}-0.011 \\
(0.021)\end{array}$ & $\begin{array}{c}-0.012 \\
(0.021)\end{array}$ & $\begin{array}{c}-0.014 \\
(0.022)\end{array}$ \\
\hline LN(EMPLOYMENT) & $\begin{array}{l}0.042^{\star *} \\
(0.019)\end{array}$ & $\begin{array}{l}0.042^{\star *} \\
(0.020)\end{array}$ & $\begin{array}{l}0.044^{\star *} \\
(0.018)\end{array}$ \\
\hline LN(WAGE_INCOME) & 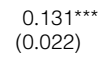 & $\begin{array}{l}0.134^{\star * *} \\
(0.020)\end{array}$ & $\begin{array}{l}0.133^{\star \star *} \\
(0.021)\end{array}$ \\
\hline POPULATION_DENSITY & $\begin{array}{l}0.089^{* * *} \\
(0.014)\end{array}$ & $\begin{array}{l}0.092^{* * *} \\
(0.014)\end{array}$ & $\begin{array}{l}0.093^{\star \star \star} \\
(0.013)\end{array}$ \\
\hline Industry and year fixed effects & Yes & Yes & Yes \\
\hline $\begin{array}{l}\text { No. of obs. (Firm-period) } \\
\text { Adj. } R^{2}\end{array}$ & $\begin{array}{l}8,973 \\
0.072 \\
\end{array}$ & $\begin{array}{l}8,973 \\
0.073 \\
\end{array}$ & $\begin{array}{l}8,973 \\
0.072\end{array}$ \\
\hline
\end{tabular}

the lockup expiration is, on average, above the offer price (PRICE_INCREASE). The results in column 2 suggest that, if after the lockup period the stock price exceeds (on average) the offer price, the difference in home price growth of ZIP codes located within 5 miles is additionally 8 bps higher compared to ZIP codes between 5 and 20 miles from the IPO headquarters' ZIP code. Including the interaction term POST LOCKUP $\times$ PRICE_INCREASE has no effect on the coefficients of POST_FILING_DATE or POST_LOCKUP. Taken together, these results suggest that both investor liquidity and wealth help explain the local economic spillover effects.

As a placebo test, we compare the effects of regular IPOs to buyout-backed IPOs. The latter have investors who are less likely to be company employees 
and/or local to the company headquarters. In column 3, we regress differences of home price growth on an indicator variable that identifies whether the IPO was buyout-backed and its interaction with post-filing, post-issue, and post-lockup period variables. The interaction term POST_FILING_DATE $\times$ BUYOUT_IPO is negative, suggesting that the lack of local investors in buyout-backed IPOs mutes the spillover effects and supports our interpretation that local investors drive IPO effects.

\section{Gentrification Effect of IPOs}

Our findings suggest that IPOs create positive spillover effects on real estate markets and local economies. Even though the spillover effects are broad and have a positive effect on local economies as a whole, the effect may be asymmetric across individual people with different income levels. For example, our baseline results suggest that IPOs affect only the market for high-priced homes in the area. This result suggests that lower-income people who own low-priced houses do not benefit from IPOs as much as higher-income individuals. ${ }^{9}$ Therefore, we hypothesize that IPO activity could crowd out low-income people, especially tenants, inducing them to move to more affordable neighborhoods.

We test whether IPO activity increases the likelihood that people move out of the IPO area to more affordable neighborhoods in the next 2 years. The Experian panel data set (2005-2015) allows us to observe the ZIP code where people reside each year and to infer when they move from one ZIP code to another. The median person in our sample has lived in two different ZIP codes during this time. We believe that for people living in apartments or multi-unit complexes, it is easier to move in response to local housing market conditions than it is for those who own their homes. Thus, we focus on these people and use homeowners of single family residences as a placebo.

To create the dependent variables in our regressions, we divide all ZIP codes in the United States into four groups, based on average household income or median rent prices. The resulting dependent variable (migration) is an indicator that equals 1 if a person moves to a lower-rent or lower-income ZIP code following an IPO, and 0 otherwise. The probability that a person will move to a different ZIP code in a given year is $12.4 \%$, which is consistent with migration statistics from the U.S. Census Bureau. ${ }^{10}$ The unconditional probability that low-income people living in apartments or complexes will move to ZIP codes with lower average income is $11 \%$, and with lower rent is $3.5 \%$.

Our findings in column 1 of Table 9 show that IPOs increase the probability that people in the lowest quartile of the income distribution move to lower-income ZIP codes. Our findings in column 2 also suggest that low-income people move to neighborhoods with lower average rents. We find no evidence that heavy SEO activity reliably affects the tendency to migrate to other ZIP codes.

\footnotetext{
${ }^{9}$ See the following article from the Wall Street Journal, "San Francisco Has a People Problem" https://www.wsj.com/articles/san-francisco-has-a-people-problem-1521691260.

10“U.S. Mover Rate Remains Stable at About 12\% Since 2008, Census Bureau Reports" Release Number CB15-47, available at https://www.census.gov/newsroom/press-releases/2015/cb15-47.html (Mar. 18, 2015).
} 
TABLE 9

Regressions Estimating Migration Patterns

In columns 1 and 2 of Table 9 , the dependent variable is an indicator variable that takes the value of 1 if within 2 years after the IPO the person moves to a ZIP code with a lower average income (column 1) or a ZIP code with lower average rent prices (column 2). A coefficient of 1 indicates a $1 \%$ change in the dependent variable, and 0 otherwise. LARGE_IPO (SEO) is an indicator variable that takes the value of 1 if the proceeds from the IPO (SEO) are in the top quartile of the distribution of IPO (SEO) proceeds. LOW_INCOME is an indicator variable that takes the value of 1 if the person's income is in the bottom quartile of the yearly distribution of incomes in that ZIP code, and 0 otherwise. The sample is people living in an apartment, condo, or another multi-family unit. We include controls for the person's credit score and marital status. Median ZIP code rental prices are from Zillow (where available). The ZIP code of a person's residence is taken from Experian (2005-2015). All regressions exclude the years of the financial crisis (2007-2009). The regressions include ZIP code and year fixed effects. We cluster at the individual and year level and report standard errors in parentheses. ${ }^{*},{ }^{* *}$, and ${ }^{* * *}$ indicate significance at the $10 \%, 5 \%$, and $1 \%$ levels, respectively.

LARGE_IPO_HQ_ZIP_CODE

LARGE_SEO

LARGE_IPO $\times$ LOW_INCOME

LARGE_SEO $\times$ LOW_INCOME

LOW_INCOME

CREDIT_SCORE

SINGLE

Year fixed effects ZIP code fixed effects

No. of obs. (Individual-year)

Adj. $R^{2}$

\begin{tabular}{cc}
\multicolumn{2}{c}{ Dependent Variable $=1$ if: } \\
\hline $\begin{array}{c}\text { Individual Moves } \\
\text { to Lower Income } \\
\text { ZIP Code }\end{array}$ & $\begin{array}{c}\text { Individual Moves } \\
\text { to Lower Rent } \\
\text { ZIP Code }\end{array}$ \\
-1.343 & 2 \\
\cline { 2 - 2 }$(0.831)$ & $-0.974^{\star \star \star}$ \\
-0.602 & $(0.191)$ \\
$(0.621)$ & -0.321 \\
$1.489^{\star \star \star}$ & $(0.360)$ \\
$(0.545)$ & $0.743^{\star}$ \\
1.054 & $(0.391)$ \\
$(0.681)$ & -0.344 \\
$4.542^{\star \star \star}$ & $(0.633)$ \\
$(0.191)$ & $1.050^{\star \star \star}$ \\
$-3.281^{\star \star \star}$ & $(0.109)$ \\
$(0.229)$ & $-0.630^{\star \star \star}$ \\
$2.438^{\star \star \star}$ & $(0.061)$ \\
$(0.321)$ & $1.324^{\star \star \star}$ \\
Yes & $(0.132)$ \\
Yes & Yes \\
644,027 & Yes \\
0.125 & 463,256 \\
& 0.051 \\
\hline
\end{tabular}

\section{Incremental Impact of IPO Activity: Intensive Margin Tests}

In our main empirical analysis, we focus on extensive margin tests that allow us to test whether IPOs create significant economic spillover effects on their local economies. To examine the intensive margin of IPO activity, we focus on economies with nonzero IPO activity. Because of the geographical spillovers we document above, and because the geography of a county is large enough to include the spillover effects, the most straightforward way to estimate the intensive margin of IPOs is a county-year panel. Using the nonzero IPO activity countyyears, our sample size is between 1,300 and 1,900 county-years, depending on the test. In all these tests, we retain our control variables and include county fixed effects and year fixed effects.

We take two approaches to quantifying IPO activity in these tests, the natural $\log$ of the proceeds, and the decile of the proceeds, each of which offers a slightly different interpretation. Specifically, in regressions (2) and (3), $\Delta(\bar{Y})$ is the average yearly difference in the outcome variable $\mathrm{Y}$ in the 2 -year period after an IPO in the county, and $\mathbf{X}$ is a vector of county-level controls (population, population 
density, per capita income, and unemployment).

$$
\begin{aligned}
\Delta(\bar{Y})_{i, t+1}= & \beta(\text { LN }(\text { IPO_PROCEEDS }))_{i, t}+\mathbf{X}_{i, t}+\alpha_{i}+a_{t}+\epsilon_{i, t+1}, \\
\Delta(\bar{Y})_{i, t+1}= & \beta(\text { DECILE_OF_IPO_PROCEEDS })_{i, t} \\
& +\mathbf{X}_{i, t}+\alpha_{i}+a_{t}+\epsilon_{i, t+1} .
\end{aligned}
$$

The results from regressing outcome variables on LN(IPO_PROCEEDS), in Table 10 using regression (2), suggests that doubling IPO proceeds from say, 180 (the mean) to 360 million, will have an average effect of increasing employment in the county by 628 (column 1), establishments by 10 (column 2), and home values by $\$ 1,228$ per home for high-end homes (column 3 ). ${ }^{11}$ Thus, when evaluated at the mean, the average number of new employees per $\$ 1$ million of IPO proceeds is approximately $628 / 180=3.5$, and the average number of new establishments is $10 / 180=0.06$. Continuing with these intensive margin tests, in regression ( 3 ) we rank each county with nonzero IPO activity within a year and put them in decile bins, such that the $10 \%$ of counties with the highest activity in terms of aggregate IPO proceeds are in bin 10, and the $10 \%$ of counties with the lowest (but still nonzero) IPO activity are in bin $1 .^{12}$

Using regression (3), we regress our outcome variables on this 1-to-10 variable of IPO intensity. The estimates suggest that moving from proceeds bin $i$ to bin $i+1$ on average in the county increases employment by 328 , establishments by 5.6 , and the per-home value of high-end homes by $\$ 797$. When evaluated at the bin 7 (mean proceeds $=\$ 111$ million) to bin 8 (mean proceeds $=\$ 179$ million, closest to the overall county average) transition, the average number of new employees per $\$ 1$ million of IPO proceeds is approximately $328 / 68=4.8$, and the average number of new establishments is 5.6/68 $=0.08$.

We interpret these calculations to suggest that for "normal" IPO activity (i.e., near the mean level of proceeds), each additional $\$ 1$ million of proceeds creates between 3.5 and 4.7 new employees county-wide and between 0.06 and 0.08 new establishments. Based on our estimates from our ZIP code-year regressions, on average, approximately $69 \%$ of these new employees are in the IPO firm's ZIP code. $^{13}$

Coupled with the previous tests in the paper, this finding suggests that there is not only a direct effect of an IPO on the local economy, but there is also a greater effect the larger is the IPO. Intensive margin tests that use change in building permits or change in mortgage amounts are not reliably distinguishable from 0 , suggesting that the IPO effect is only at the extensive margin for those variables.

\footnotetext{
${ }^{11}$ These dollar figures are not inflation adjusted, but our time fixed effects absorb inflation effects.

${ }^{12}$ We find similar results using proceeds, but prefer a logged transformation because logged proceeds is less subject to problems that could arise from outliers and the skewness of the distribution. In addition, large IPOs may have employees split among multiple locations, making our estimates from local spillover effects more conservative.

${ }^{13}$ We measure the share of employment growth in the county across different ZIP codes, using as an independent variable the total amount of proceeds in the closest ZIP code. We provide the details of the regression and the results for these estimates in Section A.III of the Supplementary Material.
} 
TABLE 10

Intensive Margin Regressions Based on a County-Year Panel of IPO Activity

In Table 10, the dependent variables in the regressions are the average yearly difference (in levels) in employment (columns 1 and 4), establishments (columns 2 and 5), and home value for top-tier houses (columns 3 and 6 ) in the 2-year period after an IPO in the county. LN(IPO_PROCEEDS) is the natural logarithm of the total amount (in \$ millions) of IPO proceeds in the county in a given year. IPO_PROCEEDS_DECILES is an integer from 1 to 10 and is equal to 1 (10) if IPO proceeds in the county are in the lowest (highest) decile of the yearly distribution of IPO proceeds, and 0 otherwise. We include controls for county population (in thousands), population density, per capita income, and the number of unemployed people (in thousands). All regressions include county and year fixed effects. We cluster at the county level and present robust standard errors in parentheses. ${ }^{*},{ }^{* *}$, and ${ }^{* * *}$ indicate significance at the $10 \%, 5 \%$, and $1 \%$ levels, respectively.

\begin{tabular}{|c|c|c|c|c|c|c|}
\hline & 1 & 2 & 3 & 4 & 5 & 6 \\
\hline LN(IPO_PROCEEDS) & $\begin{array}{l}627.899^{\star \star \star} \\
(235.698)\end{array}$ & $\begin{array}{l}10.022^{\star *} \\
(5.010)\end{array}$ & $\begin{array}{l}1227.743^{* * *} \\
(350.183)\end{array}$ & & & \\
\hline IPO_PROCEEDS_DECILES & & & & $\begin{array}{l}327.682^{\star \star \star} \\
(124.047)\end{array}$ & $\begin{array}{l}5.604^{* *} \\
(2.628)\end{array}$ & $\begin{array}{l}796.989 \text { *** } \\
(261.659)\end{array}$ \\
\hline POPULATION & $\begin{array}{l}-0.687 \\
(-0.361)\end{array}$ & $\begin{array}{l}-0.019 \\
(-0.402)\end{array}$ & $\begin{array}{l}-2.285 \\
(-0.822)\end{array}$ & $\begin{array}{l}-0.881 \\
(-0.464)\end{array}$ & $\begin{array}{l}-0.022 \\
(-0.456)\end{array}$ & $\begin{array}{l}-2.695 \\
(-0.972)\end{array}$ \\
\hline POPULATION_DENSITY & $\begin{array}{c}0.954 \\
(2.203)\end{array}$ & $\begin{array}{l}-0.092^{\star} \\
(-0.051)\end{array}$ & $\begin{array}{l}2.697 \\
(3.225)\end{array}$ & $\begin{array}{c}1.781 \\
(2.565)\end{array}$ & $\begin{array}{c}-0.069 \\
(0.055)\end{array}$ & $\begin{array}{l}2.991 \\
(3.278)\end{array}$ \\
\hline PER_CAPITA_INCOME & $\begin{array}{l}-0.136 \\
(-0.095)\end{array}$ & $\begin{array}{l}-0.008^{\star} \\
(-0.004)\end{array}$ & $\begin{array}{l}-0.755^{\star * *} \\
(-0.239)\end{array}$ & $\begin{array}{c}0.011 \\
(0.088)\end{array}$ & $\begin{array}{c}-0.004 \\
(0.004)\end{array}$ & $\begin{array}{l}-0.681^{\star \star \star} \\
(0.245)\end{array}$ \\
\hline UNEMPLOYED & $\begin{array}{l}52.403 \\
(1.376)\end{array}$ & $\begin{array}{c}1.099 \\
(0.509)\end{array}$ & $\begin{array}{l}59.708 \\
(0.857)\end{array}$ & $\begin{array}{l}38.891 \\
(1.631)\end{array}$ & $\begin{array}{c}1.223 \\
(0.566)\end{array}$ & $\begin{array}{l}69.482 \\
(1.180)\end{array}$ \\
\hline County-year fixed effects & Yes & Yes & Yes & Yes & Yes & Yes \\
\hline $\begin{array}{l}\text { No. of obs. (county-year) } \\
\text { Adj. } R^{2}\end{array}$ & $\begin{array}{l}1,796 \\
0.467\end{array}$ & $\begin{array}{l}1,796 \\
0.581\end{array}$ & $\begin{array}{l}1,322 \\
0.559 \\
\end{array}$ & $\begin{array}{l}1,796 \\
0.421\end{array}$ & $\begin{array}{l}1,796 \\
0.531\end{array}$ & $\begin{array}{l}1,322 \\
0.558\end{array}$ \\
\hline
\end{tabular}

\section{Placebo Tests and Instrumental Variables Approaches}

\section{A. Placebo IPOs}

Our identifying assumption is that cross-sectional differences in real estate, employment, and establishment growth of ZIP codes in the same county-year should be approximately the same if there is no IPO activity in that county. By performing the following placebo tests, we evaluate whether the relationship we observe in the data is spurious. We take all our treated ZIP code-years (those in which there was an IPO) and we (counterfactually) assign a random (placebo) year to each ZIP code. We retain the matched control ZIP codes, which we assign the same placebo year, and we reestimate our regressions. Because these ZIP codes experience only placebo IPOs, there should not be a significant IPO effect on the counterfactually assigned dates.

We present the regression results from the placebo tests of real estate variables and economic development in the Supplementary Material. The results suggest that placebo IPOs do not create statistically significant changes in home price growth, employment growth, establishment growth (tradable, nontradable, or construction) or credit card spending between ZIP codes in a given county-year. We conclude that our results are unlikely to be a spurious result of ZIP code-specific characteristics.

\section{B. An Off-the-Shelf Instrumental Variable Approach is Unsatisfying}

One approach to establish causality would be to use an instrumental variable (IV) to generate quasi-random variation in the IPO process. Busaba, Benveniste, 
and Guo (2001) show that poor market returns during the 30 days after an IPO's filing period are a useful predictor of whether the company will withdraw the IPO after the filing. Between $15 \%$ and $20 \%$ of IPOs filed are ultimately withdrawn. Bernstein (2015), studying whether public/private status impacts a firm's innovation, uses 60-day market returns from the filing date to instrument for IPO activity. Predicting IPO completion (as opposed to withdrawal) with market returns in a first-stage regression, he can generate plausibly exogenous variation in whether a given company becomes public or stays private. Likewise, Babina et al. (2017) use the same instrument to examine whether an IPO firm's employees leave for start-up firms.

But at least in a geographic, rather than firm-level setting, the instrument fails several criteria for validity. A study by Cornaggia, Gustafson, Kotter, and Pisciotta (2018) uses this instrument in a geographic setting and concludes that IPOs have a startlingly large negative effect on employment and income growth in their county. We conclude, though, that these large negative instrumental variable estimates stem from econometric, rather than economic, reasons, primarily due to a weak instrument that violates the necessary exclusion restriction. One source of the econometric problem is that the first-stage-adjusted $R^{2}$ is quite low (at a maximum, 3.2\% according to Table 3 in Cornaggia et al. (2018)). We independently confirm a low first-stage-adjusted $R^{2}{ }^{14}$ Perhaps the fact that the instrument fails to predict IPO withdrawals in the period after the dot-com bubble causes this lack of explanatory power. Numerous researchers suggest that a nonexogenous instrument combined with a low $R^{2}$ in the first stage can yield economically implausible estimates. $^{15}$

More importantly, however, the instrument likely fails the exclusion restriction and amplifies a negative bias in OLS estimates. First, NASDAQ returns do not affect local economies only through completed IPOs; they also affect them through acquisition activity and the wealth of shareholders in general. More than $50 \%$ of the firms that withdraw from an IPO are acquired within a few years (Cooney, Moeller, and Stegemoller (2009)). Second, there are significant factors that affect the decision to complete or withdraw an IPO (e.g., an active IPO market, venture-capital backing, and underwriter reputation) that are also correlated with the firm's location (Busaba et al. (2001), Dunbar and Foerster (2008)). Moreover, fewer than $10 \%$ of the firms that withdraw an IPO file again, suggesting that market/macroeconomic conditions explain only a small fraction of a firm's decision to withdraw, and that the instrument uses variation that is not as good as random. These findings cast further doubt of using withdrawn IPOs as a valid counterfactual.

\footnotetext{
${ }^{14}$ We include regressions of IPO completion on 2-month NASDAQ returns for various periods in Section A.IV found in the Supplementary Material.

${ }^{15}$ Jiang (2017) notes that F-statistics easily exceed the critical values in Stock and Yogo (2005) in large samples, raises concerns over the IV when $R^{2}$ is less than $2 \%$, and stresses that weak IV tests are not informative when the IV violates exogeneity. Hahn and Hausman (2003) formalize this argument and argue that if the IV is even slightly correlated with the disturbance, a low $R^{2}$ leads to a large amount of bias. They conclude: "Our findings highlight the result that when $R^{2}$ is low (below 0.1 ) OLS may do better than 2SLS.” See also Atanasov and Black (2017).
} 
No identification is perfect; however, as we argue throughout the paper, an empirical design that relies on constructing a careful counterfactual by exploiting nuanced differences in proximity to an IPO is more compelling in our economic setting than applying an off-the-shelf IV that does not satisfy the exclusion restriction. Moreover, our findings are intuitive and consistent with previous theory and empirical literature that discusses the positive effects of liquidity or wealth shocks on local real estate markets, employment, and business development.

\section{Conclusion}

We estimate the spillover effects from an IPO to the local economy in the form of increases in local labor, business, and real estate outcomes. We exploit nuanced geographical distances of a ZIP code from the IPO headquarters to identify the extensive margin and the intensive margin of the IPO spillover effects. We find that each additional $\$ 10$ million of proceeds leads to between 35 and 47 new jobs and between 0.6 and 0.8 new businesses in the county. IPO firms, which raise on average $\$ 180$ million, create approximately 630 to 850 new jobs and 10 to 15 new businesses per year in the county over the subsequent 2 years. Some of the new jobs are at the IPO firm itself, and some are created from the "multiplier effect." These economic spillovers are nontrivial and translate into economically significant increases in the annual growth rate of establishments and employment of $7 \%$ and $15 \%$, respectively. There may be additional effects if an IPO firm has operations in other counties or uses proceeds to expand geographically. ${ }^{16}$

Our findings relate to previous studies that document economic spillovers from opening a new manufacturing plant or other forms of corporate investment. However, this literature and our study differ in an important way: An IPO does not create a new firm; an IPO simply changes a firm's listing status, provides access to the equity market, and injects money into the firm. There appears to be something special about the change in listing status, because we do not find measurable economic spillover effects following seasoned equity offerings. Thus, it is unlikely that most of the effect we find arises from merely capital raising. In this respect, this paper relates to studies that investigate the role of financial markets on economic wealth and growth and contributes to the debate on whether the stock market is a sideshow. Some studies argue that the development of equity markets does not affect local economic development (Karolyi (2004)) or even has a large negative effect (Cornaggia et al. (2018)). In contrast, our evidence suggests that when firms gain better access to financial markets, there are positive spillover effects on the local economy. Our evidence on increased credit card spending suggests a plausible channel for this positive spillover effect: Employees are able to convert illiquid paper wealth into cash and subsequently spend some of their wealth, boosting the local economy.

\footnotetext{
${ }^{16}$ We note that our empirical design of using county-year fixed effects absorbs geographic and time series variation in the nature of the firms that go public. Our tests do not speak to across-industry variation in the effect of a local firm going public. Whether listings of firms in tradable sectors, like restaurant chains, or nontradable sectors, like biotech firms, have different effects on the local economy and on local businesses (Kutsuna, Smith, Smith, and Yamada (2016)) is a question we leave for further research.
} 
Moreover, our results on the effects of an IPO on consumer spending, real estate prices, and gentrification are, to our knowledge, the first in the literature. Our evidence, therefore, suggests that IPOs affect local economies through an increase in demand for local goods and services in retail and construction. Academics and regulators are also increasingly paying attention to the broad issue of the real effects of IPOs (and their declining number) (see, e.g., https://www.sec.gov/news/speech/opening-remarks-sec-nyu-dialoguesecurities-market-regulation-reviving-us-ipo-market). Finally, our findings also provide empirical support to popular press articles that discuss the ongoing debate over the local economic benefits of attracting a firm's headquarters.

\section{Supplementary Material}

Supplementary Material for this article is available at https://doi.org/10.1017/ S0022109019000188.

\section{References}

Acharya, V., and Z. Xu. "Financial Dependence and Innovation: The Case of Public versus Private Firms.” Journal of Financial Economics, 124 (2016), 223-243.

Adelino, M.; A. Schoar; and F. Severino. "House Prices, Collateral, and Self-Employment." Journal of Financial Economics, 117 (2015), 288-306.

Atanasov, V. A., and B. S. Black. "The Trouble with Instruments: Re-Examining Shock-Based IV Designs." Working Paper, Northwestern University (2017).

Babina, T.; P. Ouimet; and R. Zarutskie. "Going Entrepreneurial? IPOs and New Firm Creation." Working Paper, University of North Carolina (2017).

Barber, B. M., and J. D. Lyon. "Detecting Long-Run Abnormal Stock Returns: The Empirical Power and Specification of Test Statistics.” Journal of Financial Economics, 43 (1997), 341-372.

Beck, T., and R. Levine. "Stock Markets, Banks, and Growth: Panel Evidence." Journal of Banking and Finance, 28 (2004), 423-442.

Bekaert, G.; C. R. Harvey; and C. Lundblad. "Does Financial Liberalization Spur Growth?” Journal of Financial Economics, 77 (2005), 3-55.

Bernstein, S. "Does Going Public Affect Innovation?” Journal of Finance, 70 (2015), 1365-1403.

Bernstein, S.; E. Colonnelli; X. Giroud; and B. Iverson. "Bankruptcy Spillovers." Journal of Financial Economics, forthcoming (2019).

Bertrand, M.; E. Duflo; and S. Mullainathan. "How Much Should We Trust Differences-in-Differences Estimates?" Quarterly Journal of Economics, 119 (2004), 249-275.

Blackwell, M.; S. Iacus; G. King; and G. Porro. "cem: Coarsened Exact Matching in Stata." Stata Journal, 9 (2009), 524-546.

Borisov, A.; A. Ellul; and M. Sevilir. "Access to Public Capital Markets and Employment Growth." Working Paper, University of Cincinnati (2017).

Brown, J. R.; S. M. Fazzari; and B. C. Petersen. "Financing Innovation and Growth: Cash Flow, External Equity, and the 1990s R\&D Boom.” Journal of Finance, 64 (2009), 151-185.

Brown, J. R., and I. V. Floros. "Access to Private Equity and Real Firm Activity: Evidence from PIPEs.” Journal of Corporate Finance, 182 (2012), 151-165.

Brown, J. R.; G. Martinsson; and B. C. Petersen. "Law, Stock Markets, and Innovation.” Journal of Finance, 68 (2013), 1517-1549.

Busaba, W. Y.; L. M. Benveniste; and R. Guo. "The Option to Withdraw IPOs during the Premarket: Empirical Analysis.” Journal of Financial Economics, 60 (2001), 73-102.

Cagetti, M., and M. De Nardi. "Entrepreneurship, Frictions, and Wealth." Journal of Political Economy, 114 (2006), 835-870.

Carlino, G., and N. E. Coulson. "Compensating Differentials and the Social Benefits of the NFL." Journal of Urban Economics, 56 (2004), 25-50.

Cooney, J. W.; T. Moeller; and M. Stegemoller. "The Underpricing of Private Targets." Journal of Financial Economics, 93 (2009), 51-66.

Cornaggia, J.; M. Gustafson; J. D. Kotter; and K. Pisciotta. "Public Ownership and the Local Economy." Working Paper, Pennsylvania State University (2018). 
Dunbar, C. G., and S. R. Foerster. "Second Time Lucky? Withdrawn IPOs that Return to the Market." Journal of Financial Economics, 87 (2008), 610-635.

Gao, X.; J. R. Ritter; and Z. Zhu. "Where Have All the IPOs Gone?" Journal of Financial and Quantitative Analysis, 48 (2013), 1663-1692.

Greenstone, M., and E. Moretti. "Bidding for Industrial Plants: Does Winning a 'Million Dollar Plant' Increase Welfare?" Working Paper, National Bureau of Economic Research (2003).

Greenstone, M.; R. Hornbeck; and E. Moretti. "Identifying Agglomeration Spillovers: Evidence from Winners and Losers of Large Plant Openings.” Journal of Political Economy, 118 (2010), 536-598.

Hahn, J., and J. Hausman. "Weak Instruments: Diagnosis and Cures in Empirical Econometrics." American Economic Review, 93 (2003), 118-125.

Haltiwanger, J.; R. S. Jarmin; and J. Miranda. "Who Creates Jobs? Small versus Large versus Young." Review of Economics and Statistics, 95 (2013), 347-361.

Jayaratne, J., and P. E. Strahan. "The Finance-Growth Nexus: Evidence from Bank Branch Deregulation." Quarterly Journal of Economics, 111 (1996), 639-670.

Jiang, W. "Have Instrumental Variables Brought Us Closer to the Truth?" Review of Corporate Finance Studies, 6 (2017), 127-140.

Karolyi, G. A. "The Role of American Depositary Receipts in the Development of Emerging Equity Markets." Review of Economics and Statistics, 86 (2004), 670-690.

Kavetsos, G. "The Impact of the London Olympics Announcement on Property Prices." Urban Studies, 49 (2012), 1453-1470.

Kenney, M.; D. Patton; and J. R. Ritter. "Post-IPO Employment and Revenue Growth for U.S. IPOs, June 1996-2010.” Ewing Marion Kauffman Foundation Report (2012).

Kutsuna, K.; J. K. Smith; R. Smith; and K. Yamada. "Supply-Chain Spillover Effects of IPOs.” Journal of Banking and Finance, 64 (2016), 150-168.

Levine, R. "Finance and Growth: Theory and Evidence." In Handbook of Economic Growth, P. Aghion and S. Durlauf, eds. Amsterdam, The Netherlands: Elsevier BV (2005), 865-934.

Mian, A.; K. Rao; and A. Sufi. "Household Balance Sheets, Consumption, and the Economic Slump." Quarterly Journal of Economics, 128 (2013), 1687-1726.

Mian, A., and A. Sufi. "What Explains the 2007-2009 Drop in Employment?" Econometrica, 82 (2014), 2197-2223.

Morck, R.; A. Shleifer; R. W. Vishny; M. Shapiro; and J. M. Poterba. "The Stock Market and Investment: Is the Market a Sideshow?" Brookings Papers on Economic Activity, 1990 (1990), 157-215.

Moretti, E. “Local Multipliers.” American Economic Review, 100 (2010), 373-377.

Ritter, J. R., and I. Welch. "A Review of IPO Activity, Pricing, and Allocations.” Journal of Finance, 57 (2002), 1795-1828.

Schmalz, M. C.; D. A. Sraer; and D. Thesmar. "Housing Collateral and Entrepreneurship.” Journal of Finance, 72 (2017), 99-132.

Stock, J. H., and M. Yogo. "Testing for Weak Instruments in Linear IV Regression.” In Identification and Inference for Econometric Models: Essays in Honor of Thomas Rothenberg, D. W. K. Andrews and J. H. Stock, eds. Cambridge, UK: University Press (2005), 80-108. 